\title{
On the systematic relationships of Cearadactylus atrox, an enigmatic Early Cretaceous pterosaur from the Santana Formation of Brazil
}

\author{
David M. Unwin ${ }^{1}$
}

With 6 figures

\begin{abstract}
Cearadactylus atrox, a large pterodactyloid pterosaur represented by an incomplete skull and lower jaw from the Lower Cretaceous Santana Formation of Brazil, is a valid species. Diagnostic characters include a mandibular symphysis with a transversely expanded 'spatulate' anterior end that is considerably wider than the rostral spatula, and a third rostral tooth that has a basal diameter more than three times that of the fifth tooth. Additional diagnostic characters, contingent upon assignment of Cearadactylus atrox to the Ctenochasmatidae, include: anterior ends of jaws divaricate and containing 7 pairs of rostral teeth and 6 pairs of mandibular teeth; marked dimorphodonty, with an abrupt change in tooth morphology; and a "high cheek". 'Cearadactylus? ligabuei' Dalla Vecchia, 1993, based on an incomplete skull, also from the Santana Formation, is not related to Cearadactylus atrox, exhibits several ornithocheirid synapomorphies and is referred, tentatively, to Anhanguera. Cearadactylus atrox exhibits various synapomorphies of the Ctenochasmatidae (rostrum anterior to nasoantorbital fenestra greater than half total skull length, teeth in anterior part of dentition relatively elongate and pencil-shaped, premaxilla has at least 7 pairs of teeth), the defining synapomorphy of the Gnathosaurinae (rostrum with dorsoventrally compressed laterally expanded spatulate anterior expansion), and shares two synapomorphies with the Chinese gnathosaurine Huanhepterus quingyangensis (anterior tips of jaws divaricate, teeth restricted to anterior half of mandible). Two elongate cervical vertebrae, also from the Santana Formation and previously assigned to 'Santanadactylus brasilensis', are tentatively referred to Cearadactylus. Reconstruction of the temporal history of the Ctenochasmatidae suggests that while ctenochasmatines became increasingly specialised for filter feeding, gnathosaurines changed from sieve feeding to piscivory, acquiring several cranial characters that are similar to those of ornithocheirids, a group that also includes large aerial piscivores that used a terminal tooth grab for prey capture.
\end{abstract}

Key words: Pterosaur, Lower Cretaceous, Brazil, Cearadactylus, Ctenochasmatidae.

\section{Zusammenfassung}

Cearadactylus atrox aus der Santana-Formation (Unterkreide, NO-Brasilien) ist eine valide Art. Eine Revision des Taxons, von dem ein unvollständiger Schädel mit Unterkiefer vorliegt, ergab folgende diagnostische (autapomorphe) Merkmale. Die Symphyse hat ein transversal verbreitertes spatelförmiges Vorderende, das deutlich breiter ist als das Schnauzenende. Der dritte rostrale Zahn erreicht einen basalen Durchmesser, der jenen des fünften Zahns um das Dreifache übertrifft. Hinzu kommen Merkmale, die C. atrox mit der Ctenochasmatidae gemein hat, darunter die vorn auseinanderklaffenden Kieferränder, sieben rostrale Zahnpaare, sechs Unterkieferzahnpaare, eine ausgeprägte Dimorphodontie sowie eine hohe Wangenregion. 'Cearadactylus ? ligabuei' Dalla Vecchia 1993, ebenfalls mit einem unvollständigen Schädel belegt, ist nicht näher mit $C$. atrox verwandt. Im Gegensatz zu letzterem zeigt 'C. ? ligabuei' signifikante Ähnlichkeiten mit den Ornithocheiridae. Unter Vorbehalt wird er hier der Gattung Anhanguera zugeordnet. C. atrox hat neben eindeutigen Synapomorphien der Ctenochasmatidae, z. B. erreicht das Rostrum anterior des nasoantorbitalen Fensters mehr als die halbe Schädellänge, die vordersten Zähne sind verlängert und stiftförmig und die das Prämaxillare trägt mindestens sieben Zahnpaare. Daneben besitzt $C$. atrox auch noch die entscheidende Synapomorphie der Gnathosaurinae, nämlich ein Rostrum mit dorsoventral komprimierter vorderem Auswuchs. Außerdem ist C. atrox gekennzeichnet durch zwei Autapomorphien des Gnathosaurinen Huanhepterus quingyangensis aus China: divergierende Schnauzenenden und Zähne begrenzt auf vordere Kieferhälfte. Schließlich werden zwei lange Halswirbel, die auch aus der Santana Formation stammen und bislang zu Santanadactylus brasiliensis gerechnet wurden, unter Vorbehalt zu Cearadactylus gestellt. Die Evolutionsgeschichte der Ctenochasmatidae ist durch eine zunehmende Spezialisierung auf filternde Ernährungsweise gekennzeichnet. Die Gnathosaurinen dagegen stellten sich von der filternden auf eine piscivore Ernährung um, wobei sie eine Reihe von Schädelmerkmalen erworben haben, die den Ornithocheiriden konvergent ähnlich ist.

Schlüsselwörter: Pterosaurier, Unter-Kreide, Brasilien, Ornithocheiridae, Ctenochasmatidae.

\footnotetext{
1 Museum für Naturkunde der Humboldt-Universität, Institut für Paläontologie, Invalidenstr. 43, D-10115 Berlin, Germany. Received April, accepted July 2002
} 


\section{Introduction}

The Romualdo Member of the Lower Cretaceous Santana Formation of Brazil has yielded a remarkably well preserved and diverse pterosaur assemblage (e.g. Campos \& Kellner 1985, Wellnhofer 1985, 1987, 1991a, b, c, Unwin 1988, Kellner 1990, Martill 1993, Kellner \& Tomida 2000). Unlike most fossils of pterosaurs, skeletons are often preserved uncrushed (e.g. Wellnhofer 1988, 1991c), although they are rarely complete (Kellner \& Tomida 2000), and some examples of soft tissue preservation have also been reported (Campos et al. 1984, Martill \& Unwin 1989, Martill et al. 1990, Kellner 1997). A surprising aspect is the apparent diversity of this assemblage: 17 species distributed among 9 genera representing at least 3 families have been reported so far (Kellner \& Tomida 2000: table 9). This excludes taxa from the Crato Formation which has been included in the Santana Formation (e.g. Maisey 1991), but is now recognised as a distinct unit (Martill \& Wilby 1993), perhaps as much as 10 million years older, although with a rather similar pterosaur assemblage (Frey \& Martill 1994, Martill \& Frey 1998, 1999, Sayão \& Kellner 2000).

Various workers (e.g. Wellnhofer 1987, 1991c, Unwin 1988, 2001, Kellner \& Tomida 2000) have suggested that the apparent species diversity of the Santana Formation assemblage may have been inflated by excessive taxonomic splitting, leading to a situation that closely resembles early stages in the development of the taxonomic understanding of other pterosaur assemblages such as the Solnhofen Limestone (Wellnhofer 1970, 1975a) and the Cambridge Greensand (Wellnhofer 1978, Unwin 2001). In the case of the Santana Formation, oversplitting can be partially attributed to the non-comparability of some species because of incomplete preservation (Wellnhofer 1987, 1991c, Kellner \& Tomida 2000). More problematic, however, has been the assignment of decisive taxonomic value to questionable characters such as size, the degree of fusion of skeletal elements and, most controversially, the morphology and position of cranial crests. The latter are widely distributed among Santana pterosaurs and have often been cited as key diagnostic features (e.g. Campos \& Kellner 1985, Kellner \& Tomida 2000), even though their variation and distribution are still poorly understood, and their function unclear (Plieninger 1907, Bennett 1993, 2002).

A second problem concerns the relationships of Santana pterosaurs to each other and to taxa from other deposits. Two distinct approaches are discernable. Some workers (e.g. Price 1971, Wellnhofer 1977, 1985, Buisonjé 1980, Kellner 1984, Campos \& Kellner 1985, Leonardi \& Borgomanero 1985, Kellner 1989) have erected new genera and even families for Santana pterosaurs, subsequently assigning similar forms from other Cretaceous deposits to these taxa (e.g. Kellner \& Tomida 2000). Others (e.g. Fastnacht 2001, Unwin 2001) have argued that some species of Santana pterosaurs belong within previously established genera such as Ornithocheirus Seeley, 1869 and Coloborhynchus Owen, 1874, both based on material from the late Lower Cretaceous of England (see Unwin 2001). The situation is even more confused at higher taxonomic levels with, for example, some authors continuing to use the name Anhangueridae Campos \& Kellner, 1985, even though as I have noted elsewhere (Unwin 2001) the content and diagnosis of this family is practically identical to that of the Ornithocheiridae Seeley, 1870, an older and thus senior synonym.

Revision of the taxonomy and relationships of Santana pterosaurs is needed if the potential of this important assemblage for understanding the anatomy, functional morphology, ecology and evolutionary history of pterosaurs is to be fully realised. Here, attention is focused on one of the earliest and most unusual pterosaurs to be described from the Santana Formation, Cearadactylus, currently represented by two species: Cearadactylus atrox Leonardi and Borgomanero, 1985 and 'Cearadactylus? ligabuei' Dalla Vecchia, 1993, although the latter is only tentatively assigned to this genus. This study set out to answer four questions: (1) Is Cearadactylus atrox a distinct, diagnosable and valid taxon? (2) Can the relationship of 'Cearadactylus? ligabuei' to $C$. atrox be resolved? (3) What are the relationships of C. atrox to other pterosaurs? (4) Can any other fossil material from the Santana Formation be assigned to C. atrox?

Two circumstances allow these questions to be answered. First, recent systematic revisions of Santana pterosaurs (e.g. Fastnacht 2001) and related assemblages such as that from the Cambridge Greensand (Unwin 2001), together with work now underway on other undescribed specimens, are helping to resolve the taxonomy of Cretaceous pterosaurs and provide a clearer and more robust taxonomic framework against which C. atrox and 'C.? ligabuei' can be more effectively assessed. Secondly, recent studies of the interrelationships of pterosaurs (Howse 1986, 
Bennett 1989, 1994, Unwin 1992a, 1995, in press, Unwin \& Lü 1997, Unwin et al. 2000, Kellner 1996, Peters 1997, Viscardi et al. 1999), have greatly improved our understanding of pterosaur phylogeny and can be used to reassess the relationships of Cearadactylus.

In this work, paraphyletic taxa are denoted by enclosure in double quotation marks. Invalid taxonomic names or those of doubtful validity are indicated by citation in single quotation marks. Notwithstanding the remarks above, the Santana Formation pterosaur Anhanguera still presents a particular taxonomic problem. Using new material, Fastnacht (2001) has convincingly demonstrated that 'Tropeognathus' robustus Wellnhofer, 1987, also from the Santana Formation, should be assigned to Coloborhynchus. Frey \& Martill (in press) point out that the holotype and only known specimen of 'Anhanguera piscator' (NSM-PV 19892) is identical to the two specimens representing Coloborhynchus robustus, an opinion which is supported here. 'Anhanguera piscator' Kellner \& Tomida, 2000 is thus treated here as a junior synonym of Coloborhynchus robustus (Wellnhofer, 1987). Additionally, since other species of Anhangera are similar to C. robustus, this raises the possibility that Anhanguera may be a junior synonym of Coloborhynchus (Frey \& Martill in press). Until this issue is resolved, however, I prefer to retain Anhanguera, at least for the reception of $A$. blittersdorffi and other nominal species including $A$. araripensis (Wellnhofer, 1985) and A. santanae (Wellnhofer, 1985).

\section{Institutional abbreviations}

BSP, Bayerische Staatssammlung für Paläontologie und Geologie, Munich, Germany; CSRL, Centro Studi e Ricerche Ligabue, Venice, Italy; DNPM, Departamento Nacional Produção Mineral, Brazil; F-PV, Borgomanero Collection, Rua Almirante Tamandaré 915, 8000 Curitiba PR, Brazil; GIUA, Geological Institute, University of Amsterdam, The Netherlands; IMCF, Iwaki Coal and Fossil Museum, Iwaki, Japan; NSM, National Science Museum, Tokyo, Japan.

\section{A history of the study of Cearadactylus atrox}

The name Cearadactylus atrox was first introduced by G. Leonardi and G. Borgomanero in 1983, for a new pterosaur from the Lower Cretaceous Santana Formation of Brazil, although the circumstances of its publication, in an abstract of the 7th Brazilian Congress of Paleontology, rendered the name a nomen nudum. The first valid use of the name, accompanied by a detailed description and illustrations of the holotype, an incomplete skull and lower jaw, appeared two years later (Leonardi \& Borgomanero 1985). This was the fifth pterosaur species to be described from the Santana Formation, but only the second based on skull material, and the first represented by an associated rostrum and mandibles. To date, and despite the large number of pterosaur remains reported from the Santana Formation since 1985, no further material, cranial or postcranial, has been referred to this species.

According to Leonardi \& Borgomanero (1983, 1985), features such as the spatulate ends of the rostrum and mandibular symphysis, the heterodont dentition and the absence of a cranial crest distinguished $C$. atrox from all previously described pterosaurs, including the two forms to which it was most similar, Gnathosaurus subulatus H. v. Meyer, 1834 and Huanhepterus quingyangensis Dong, 1982. Leonardi \& Borgomanero (1985) were unable to make any direct comparisons with the first three pterosaurs to be described from the Santana Formation: Araripesaurus castilhoi Price, 1971, based on an incomplete right forelimb; Araripedactylus dehmi Wellnhofer, 1977, a wing-finger phalanx, and Santanadactylus brasilensis Buisonjé, 1980, represented by an incomplete shoulder girdle and associated humerus described together with two associated cervicals from another individual and almost certainly not from the same taxon (Kellner \& Tomida 2000, see also below). This left open the possibility that the holotype of $C$. atrox might belong to one of these three taxa. In addition, Leonardi \& Borgomanero (1985) did not mention Brasileodactylus araripensis, described the previous year by Kellner (1984) on the basis of an anterior portion of a mandibular symphysis. However, in his account of this pterosaur Kellner (1984) noted various features, including the absence of divaricate jaw tips, that appeared to distinguish it from Cearadactylus atrox.

The following year, Campos \& Kellner (1985) described another new Santana pterosaur, Anhanguera blittersdorffi, based on a complete skull lacking mandibles. According to these authors, C. atrox was clearly distinct from $A$. blittersdorffi because it lacked a sagittal crest, and had divaricate jaw tips and a differently shaped nasoantorbital fenestra. In the same year, Wellnhofer (1985) described a series of new species from the Santana Formation, two of which, Santanadactylus araripensis Wellnhofer, 1985 and Araripe- 
saurus santanae Wellnhofer, 1985, were represented by cranial remains, but in this work no comparisons were made with $C$. atrox. Additional material, including a complete skull of $A n$ hanguera santanae was later described by Wellnhofer (1991c), but again comparisons with other Lower Cretaceous taxa omitted any discussion of C. atrox. The same occurred in 1987, when Wellnhofer erected another new genus, 'Tropeognathus', containing two species, 'T.' mesembrinus, based on a complete skull and lower jaw, and ' $T$.' robustus, represented by an incomplete lower jaw, even though, apart from the sagittal crest, the latter is rather similar to $C$. atrox. Later, Fastnacht (2001) described further material of ' $T$.' robustus, but assigned this species to Coloborhynchus, and noted that although $C$. atrox "has a very similar heterodont dentition and lateral expansion of the anterior parts of the upper and lower jaw" it could be distinguished from $C$. robustus by the absence of a medial crest on the upper and lower jaw, the different orientation of the first pair of teeth and the "festoonation" of the upper jaw.

Further new Santana Formation taxa, Tupuxuara (Kellner \& Campos 1988) and Tapejara (Kellner 1989), were described in the late 1980s, but these forms, with their edentulous jaws, were immediately distinguishable from Cearadactylus atrox. Recently, another toothed species was added to the register of Santana Formation pterosaurs, with the description of 'Anhanguera piscator' Kellner \& Tomida, 2000, represented by an almost complete skeleton including a superbly preserved skull and lower jaw. In this paper the authors also discussed Cearadactylus atrox, and concluded that it could be distinguished from other Santana taxa, but only by virtue of a single character; the greater lateral expansion of the rostral portion of the dentary compared to the premaxilla. Kellner \& Tomida (2000) also noted that, in many respects, $C$. atrox was similar to other Santana forms, especially Brasileodactylus araripensis (see also Sayão \& Kellner 2000).

In 1993 a new pterosaur, 'Cearadactylus? ligabuei', based on a fragmentary rostrum (CSRL 12692/12713) from the Santana Formation, Chapada do Araripe, Brazil, was described by Dalla Vecchia and tentatively assigned to Cearadactylus. In support of this decision, the author cited the concave outline of the anterior part of the maxilla, the relatively large size of the premaxillary teeth, the long, low shape of the skull with a spatulate rostrum and absence of a sagittal crest. No further material has been assigned to this taxon to date and its status has only been discussed by Kellner \& Tomida (2000). These authors raised the possibility that the holotype might be a composite specimen and dismissed nearly all the proposed diagnostic characters of the species because they could be found in other pterosaurs, were not considered significant, or were questionable because of poor preservation. This still left two putatively diagnostic features: the relatively large size of the rostrum and the relatively large number of teeth (22) in the jaw anterior to the nasoantorbital fenestra. Kellner and Tomida (2000) also cast doubt on all three characters used to assign ' $C$.? ligabuei' to Cearadactylus and concluded that the two species did not share any unique features.

Ideas regarding the systematic affinities of Cearadactylus also have a chequered history. In the initial description Leonardi \& Borgomanero (1983) tentatively assigned Cearadactylus to the Ornithocheiridae, but later abandoned this idea and cited the taxon as Pterodactyloidea indet. (Leonardi \& Borgomanero 1985: 75). This was followed by later workers (e.g. Wellnhofer 1991b), until Wellnhofer (1991c) erected a separate family, the Cearadactylidae, for this pterosaur (see also Wellnhofer 1991a). This proposal was adopted by Dalla Vecchia (1993), but not by Unwin (1992b, 2001) who assigned Cearadactylus to the Gnathosaurinae, which, together with the Ctenochasmatinae, forms the monophyletic taxon Ctenochasmatidae (see also Unwin et al. 2000: 197, table 4). Kellner \& Tomida (2000) rejected all previous classifications, however, and identified Cearadactylus as a member of the Pteranodontoidea (sensu Kellner 1996) and closely related to, though not a member of, the Anhangueridae (= Ornithocheiridae).

In summary, while Cearadactylus atrox is generally accepted to be a distinct and valid species, few diagnostic characters have yet been identified and comparisons with other taxa from the Santana Formation and deposits of a similar age are highly variable. The validity of 'Cearadactylus? ligabuei' seems rather more doubtful because the two remaining putatively diagnostic characters recognised by Kellner \& Tomida (2000) are variable in other pterosaurs, and might simply be related to the relatively large size of the specimen (see below). Moreover, there is no clear evidence, at present, to support the assignment of this species to Cearadactylus (Kellner \& Tomida 2000). 


\section{Systematic review}

Pterosauria Kaup, 1834

Pterodactyloidea Plieninger, 1901

\section{Ctenochasmatoidea Unwin, 1995}

Remarks: Kuhn (1967: fig. 24d) first indicated that the "Pterodactylidae" and the Ctenochasmatidae may be more closely related to each other than to other pterosaurs. Unwin (1995) formally proposed the name Ctenochasmatoidea for the clade "Pterodactylidae" + Ctenochasmatidae, noting that the "Pterodactylidae" was probably paraphyletic. Apomorphies supporting the clade Ctenochasmatoidea include: quadrate oriented in an almost horizontal position; occiput faces ventrally; and the squamosal lies level with or below the orbit. Unwin \& Lü (1997) gave further details of these characters and added a fourth character, elongation of the cervical vertebrae, although Cycnorhamphus, a basal ctenochasmatoid that has relatively short cervicals (Quenstedt 1855, Plieninger 1907, Bennett 1996) shows the primitive state for this character. Unwin (in press) gives a detailed discussion of all four characters and a formal definition of the Ctenochasmatoidea (Cycnorhamphus suevicus, Pterodaustro guinazui, their most recent common ancestor, and all its descendants). Additionally, Unwin et al. (2000: fig. 6) noted two morphometric characters, the relative elongation of the third metatarsal compared to the tibia, and the relative elongation of the ulna compared to the femur, that were characteristic of ctenochasmatoids, but only members of the Ctenochasmatinae (Ctenochasma, Pterodaustro and Eosipterus) clearly show the derived condition.

A new analysis of pterosaur phylogeny (Unwin in press), based on 20 taxa and 60 characters, confirmed the monophyly of the Ctenochasmatoidea, but modified the content of this taxon. The Lonchodectidae, a poorly known group of Cretaceous pterodactyloids (Unwin 2001), were found to nest within this clade, either in a trichotomy with Pterodactylus and the Ctenochasmatidae, or as a sister taxon to the Ctenochasmatidae.

\section{Ctenochasmatidae Nopcsa, 1928}

Definition: Gnathosaurus subulatus, Pterodaustro guinazui, their most recent common ancestor and all descendants of that ancestor.
Included taxa: Gnathosaurinae and Ctenochasmatinae.

Diagnosis: Rostrum anterior to nasoantorbital fenestra forms more than half the total length of the skull (tip of rostrum to occipital condyle). Anterior end of rostrum dorsoventrally compressed and rounded (Wellnhofer 1970, 1978). At least 25 teeth per side in the rostrum. Seven, or more, pairs of teeth in the premaxillae. Teeth project laterally from the dental border of the rostrum at least in the anterior part of the dentition (Wellnhofer 1970, 1978, Buisonjé 1981). Teeth in anterior part of dentition relatively elongate with a long cylindrical crown of even width and a short, tapering, distal tip (Buisonjé 1981, Knoll 2000). Metatarsal III more than one third the length of the tibia (Unwin et al. 2000: fig. 6a).

Remark s: Nopcsa (1928) proposed the subfamily Ctenochasmatinae for the reception of Ctenochasma and Gnathosaurus. Kuhn (1967) promoted this taxon to the Ctenochasmatidae, but omitted Gnathosaurus, although the latter was subsequently reassigned to this family by Wellnhofer $(1970,1978)$. Pterodaustro also clearly belongs within this taxon (e.g. Wellnhofer 1978), and shares a closer relationship to Ctenochasma than to any other pterosaur (Kellner 1997, Chiappe et al. 2000). The Pterodaustridae is thus a junior synonym of the Ctenochasmatidae (Nopcsa 1928) and should be abandoned. Dong (1982) assigned Huanhepterus to the Ctenochasmatidae, as has been accepted by later workers (e.g. Wellnhofer 1991a, Howse \& Milner 1995). Plataleorhynchus, a form similar to Gnathosaurus, was referred to the Ctenochasmatidae by Howse \& Milner (1995), and Unwin (1992b), Unwin \& Lü (1997) and Unwin et al. (2000) have suggested that Cearadactylus also belongs within this clade. Eosipterus (Ji \& Ji 1997) may also belong within the Ctenochasmatidae (Unwin et al. 2000), a proposal that is supported by a new, more complete specimen recently recovered from the Yixian Formation (Lü pers. comm. 2002).

Not all taxa included within the Ctenochasmatidae necessarily exhibit all apomorphies of the group. Huanhepterus and Cearadactylus, for example, have fewer than 25 teeth per side in the rostrum, but exhibit other apomorphies of the clade. In addition, some taxa not included in the Ctenochasmatidae exhibit apomorphies of the group. Pterodactylus kochi and P. antiquus, for example, have third metatarsals that are more 
than one third the length of the tibia and $C y$ cnorhamphus has a rostrum that is dorsoventrally compressed. Notably, however, these occurrences of the derived condition appear in taxa closely related to ctenochasmatids and further strengthen support for monophyly of the Ctenochasmatoidea.

\section{Gnathosaurinae Unwin, 1992b}

Definition: Gnathosaurus subulatus, Huanhepterus quingyangensis, their most recent common ancestor and all descendants of that ancestor.

Included taxa: Gnathosaurus, Plataleorhynchus, Huanhepterus, Cearadactylus.

Diagnos is: Rostrum with rounded, dorsoventrally compressed, laterally expanded spatulate, anterior expansion.

Remarks: Gnathosaurines are distinguished from other ctenochasmatoids by the transverse expansion of the anterior tip of the rostrum and the mandibular symphysis into a rounded spatula from which teeth project to form a distinct rosette that probably functioned as a grab for trapping or catching prey. All other ctenochasmatoids, with the possible exception of Ctenochasma porocristata which has a slightly expanded jaw tip (Buisonjé 1981), have jaw tips that are not transversely expanded anteriorly and taper to a rounded termination. Anteriorly expanded jaws also occur in, and are diagnostic of, the Ornithocheiridae (see Unwin 2001). However, the condition in ornithocheirids differs from that in gnathosaurines in that the anterior expansion usually contains only a few pairs of teeth, is abruptly terminated anteriorly, with a relatively flat anterior face and, unlike the dorsoventrally compressed condition evident in gnathosaurines, the spatula is at least as deep (dorsoventrally) as it is wide (transversely).

\section{Cearadactylus Leonardi \& Borgomanero, 1985}

Diagnosis: Expanded, spatulate anterior end of mandibular symphysis considerably wider than corresponding expansion of the rostrum (see also Kellner \& Tomida 2000); basal diameter of third rostral tooth more than three times the basal diameter of the fifth tooth.

Included species: Cearadactylus atrox Leonardi \& Borgomanero, 1985.

\section{Cearadactylus atrox Leonardi \& Borgomanero, 1985}

Holotype: F-PV-93, incomplete skull with mandibles partially enclosed in concretions, Leonardi \& Borgomanero 1983, 1985: figs 1-2, Wellnhofer 1991a: 127; Kellner \& Tomida 2000: figs 64-65. A plastotype is deposited in the Department of Paleontology, DNPM, Rio de Janeiro, Brazil.

Type locality: Araripe plateau, possibly from the eastern end (Leonardi \& Borgomanero 1985), Ceará, Brazil.

Horizon: Santana Formation, Araripe Group, Lower Cretaceous, Albian. Berthou et al. (1990) and Pons et al. (1990) have dated the Crato Formation as Upper Aptian to Lower Albian which means that the overlying Santana Formation is at least Middle to Upper Albian, or possibly even younger (Martill \& Wilby 1993).

Referred material: Two associated cervical vertebrae (GIUA M 4895; Buisonjé 1980: fig. 5, plate 2) also from the Santana Formation, Brazil, are tentatively assigned to this species.

Diagnosis: As for the genus.

\section{Description}

Published information and additional illustrations kindly supplied by $\mathrm{G}$. Leonardi show that the holotype (Fig. 1A-D) consists of a rostrum with parts of the cheek region (jugal, quadratojugal and quadrate) and an associated, complete lower jaw. The specimen is three dimensional, but has not been completely prepared from the matrix. The left side appears to be almost fully articulated, but on the right side the cheek region has been displaced somewhat ventral to the rostrum. The cortical bone is often in poor condition (e.g. Kellner \& Tomida 2000: fig. 65) and bone sutures are difficult to trace. The tips of some of the teeth have been restored (Kellner \& Tomida 2000: fig. 64), especially in the anterior part of the dentition on the left side.

The preserved part of the skull is $536 \mathrm{~mm}$ long and the mandible is $482 \mathrm{~mm}$ in length. Wellnhofer (1991b) calculated that the original length of the skull was approximately $570 \mathrm{~mm}$. In other ctenochasmatids represented by complete skulls (Ctenochasma gracile, Gnathosaurus subulatus, Pterodaustro guinazui) the portion of the skull corresponding to that preserved in Cearadactylus atrox occupies $89-93 \%$ of total skull length. An average of $91 \%$ yields a complete skull length 


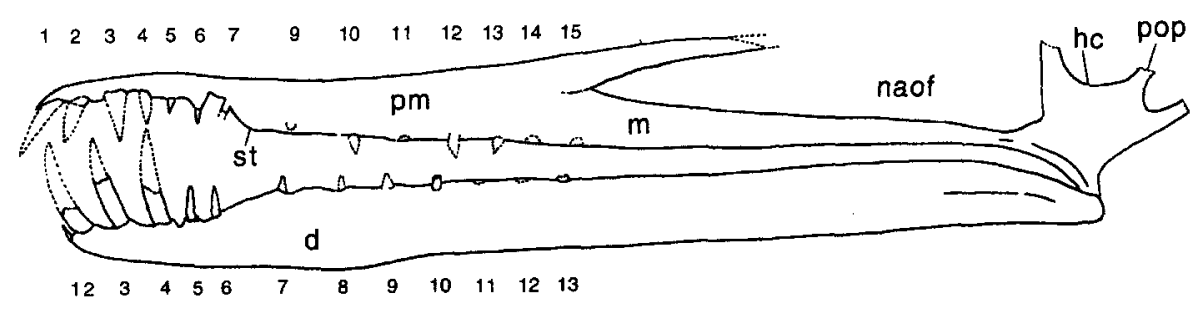

A

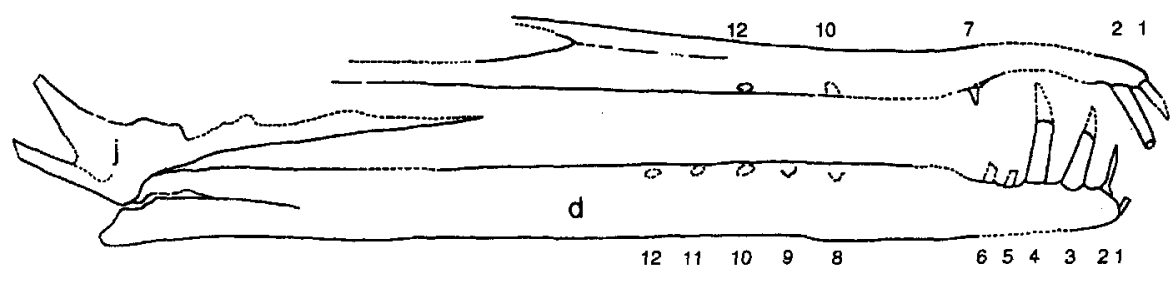

B

Fig. 1. Cearadactylus atrox (FPV-93) from the Romualdo Member, Santana Formation, of Brazil. Cranium and mandible in (A) left lateral and (B) right lateral view. Sketch of the anterior ends of the jaws in (C) left lateral and (D) slightly oblique dorsolateral view. Incomplete or broken edges indicated by a dotted line, restored margins by a dashed line. Abbreviations: d, dentary; g, groove; he, high cheek; $\mathbf{j}$, jugal; $\mathbf{m}$, maxilla; naof, nasoantorbital fenestra; pm, premaxilla; pop, postorbital process of jugal; st, step; 1-15, tooth positions. Scale bar $=50 \mathrm{~mm}$.

for C. atrox of $589 \mathrm{~mm}$. Other pterosaurs with skulls of a similar size, for example, Coloborhynchus robustus (Kellner \& Tomida 2000), have wingspans of $4-5 \mathrm{~m}$, and although this is slightly larger than the $3-4 \mathrm{~m}$ suggested by Leonardi \& Borgomanero (1985) a wingspan in this size range is also likely for $C$. atrox.

Cranium: The rostrum is remarkably long and low. In lateral view (Fig. 1A, B) the dorsal profile of the anterior portion (equivalent to the first seven dental alveoli) is slightly convex, while caudal to this region the profile is gently concave. An unusual feature is the development of a groove, between the left and right premaxillae on the dorsal surface (Kellner \& Tomida 2000: fig. 64b; Fig. 1D), that extends from the anterior tip of the jaw to a point above the anterior end of the nasoantorbital fenestra (Leonardi \& Borgomanero 1985). The significance of this structure is unclear, although one possibility is that in life it accomodated the base of an unossified sagittal crest.

Seen from the left or right side, the bar that forms the dorsal boundary of the nasoantorbital fenestra, composed of the fused premaxillae, is directed caudally and only slightly dorsally, the caudal extrapolation continuing at a somewhat shallower angle than shown in previous reconstructions of the skull (Leonardi \& Borgomanero 1985: fig. 2c, Wellnhofer 1987: fig. 1, Dalla Vecchia 1993: fig. 7, Kellner \& Tomida 2000: fig. 70a). This suggests that the cranium was somewhat lower than in these reconstructions, a supposition that is supported by other features, discussed below.

The anterior part of the rostrum has a spatulate outline in dorsal aspect (Fig. 1D). The spatula has a narrow oval shape, is widest at a point level with the fourth pair of dental alveoli then gradually narrows caudally, the greatest constriction of the rostrum occurring at a point between the seventh and eighth pair of alveoli. Anterior to its widest point the spatula gently narrows, then is truncated, with a rather flat anterior profile. A notable feature of the spatula, typical of gnathosaurines, is its marked dorsoventral compression, such that its transverse width is considerably greater than its depth. Posterior to the spatula the rostrum shows a pronounced increase in depth (Fig. 1A, B). This marked "step", 
evident on both left and right sides of the specimen and which appears to represent the relatively abrupt anterior termination of the maxilla, is an unusual feature in pterosaurs and only clearly seen in one other form, Huanhepterus quingyangensis (Dong 1982: fig. 1). Usually, in pterosaurs, the ventral margin of the skull follows a smooth continuous course with no steps, or notches (Wellnhofer 1978: figs 2, 4-5). One consequence of the condition in $C$. atrox, which is mirrored in the lower jaw, is the development of a prominent divergence between the anterior tips of the jaws, such that even at full occlusion there was a large gap between the anterior ends of the rostrum and the mandibular symphysis. Presumably, the primary role of this opening was to accommodate the first four pairs of teeth, which are highly enlarged and fang-like (Fig. 2A).

The nasoantorbital fenestra appears to have had a triangular outline, as is typical for derived pterosaurs but, with the exception of Ornithocheirus mesembrinus (Wellnhofer 1987: fig. 2a), it is more elongate than in any other pterodactyloid. A notable feature is the right-angled internal posteroventral corner formed by the lacrimal and maxillary processes of the jugal. Unlike the condition in the Ornithocheiroidea, as shown, for example, by Anhanguera (Wellnhofer 1985: figs 3, 32) and Pteranodon (Bennett 2001: figs 7, 11-12), there is no rounded, bony infilling of this angle.

As is typical for pterodactyloids the jugal has four processes. The maxillary process extends forwards to unite with the jugal process of the maxilla in an extraordinarily long and slender bar of bone that bounds the ventral border of the nasoantorbital fenestra. The lacrimal process is directed vertically, but its contact with the lacrimal is not preserved. Only the base of the postorbital process of the left jugal is preserved, but a longer, slightly tapering portion is present in the right jugal. Published drawings (Leonardi \& Borgomanero 1985: fig. 2a) and reconstructions (Leonardi \& Borgomanero 1985: fig. 2c, Wellnhofer 1987: fig. 1, Dalla Vecchia 1993: fig. 7, Kellner \& Tomida 2000: fig. 70a) of the postorbital process show it standing in a subvertical position, but it is clear from the preserved part of the right cheek region (e.g. Leonardi \& Borgomanero 1985: fig. 1c) that this process only diverged at a low angle from the quadrate (Fig. 1A). Combining evidence from the right and left sides of the skull thus shows that the postorbital process was directed at an angle of approximately $45^{\circ}$ to the ventral margin of the skull (Fig. 2A). Consequently, the orbit had a much flatter and longer (antero-posterior) basal margin, than the constricted outline shown in reconstructions so far (Fig. 2B-D). It also indicates that the lower temporal fenestra extended forward beneath the orbit, rather than being largely confined to a position behind this opening.

An unusual feature of the jugal is the degree to which the angle between the lacrimal and postorbital processes has been infilled with bone. Many pterodactyloids, including most ctenochasmatoids, show the primitive condition with little or no infilling - termed here the "low cheek". Several taxa (Dsungaripterus, derived ornithocheiroids, Cearadactylus) exhibit the "high cheek" condition, wherein the angle between the postorbital and lacrimal processes is filled by a thin sheet of bone, raising the ventral border of the orbit above the ventral margin of the nasoantorbital fenestra, and markedly increasing the depth of the "body" of the jugal. This development, probably related to mechanical strengthening of the skull to withstand relatively heavy or sudden loading of the jaws, would appear to be homoplastic within pterodactyloids because it occurs in at least three unrelated groups each of which has sister taxa (Germanodactylus, Istiodactylus and Gnathosaurus) exhibiting the primitive "low cheeked" condition. Furthermore, the argument for homoplasy is strengthened by the different pattern of development in Dsungaripterus, where the infilling begins through the ossification of a bony bar isolating a distinct lower opening that is gradually infilled (Young 1973: figs 1-3). By contrast, in ornithocheiroids, and presumably in Cearadactylus, a single lamina is developed in the same position.

The slender rod of bone forming the ventral margin of the lower temporal opening is composed of the quadrate, the quadrate process of the jugal and possibly a small contribution from the quadratojugal (Leonardi \& Borgomanero 1985: fig. 2a), although bone contacts are difficult to distinguish (Kellner \& Tomida 2000). As Leonardi \& Borgomanero (1985: fig. 2a) and Kellner \& Tomida (2000: fig. 70) show, the quadrate and associated bones lie at a remarkably shallow angle $\left(20^{\circ}\right)$ to the ventral margin of the skull, whereas in other reconstructions (Wellnhofer 1987, Dalla Vecchia 1993; Fig. 2C) this structure is oriented more steeply than is evident in the original material. The remarkably low angle of the quadrate is an important character of ctenochasmatoids (although it appears homoplastically in other pterodactyloids including Zhejiangop- 
terus and Quetzalcoatlus) and is directly related to the relatively low cranium in this clade (Unwin \& Lü 1997, Unwin in press).

Another derived character of the suspensorium is the ventral position of the quadrate articulation, well below the line of the dental margin of the rostrum (Fig. 1A, B). The primitive condition, in which the quadrate articulation lies at the same level as the ventral margin of the skull is evident in basal pterosaurs including dimorphodontids and campylognathoidids (Wellnhofer 1978), and in some pterodactyloids such as $T u$ puxuara (IMCF 1052) where it presumably represents a reversal to the primitive state. Ornithocheiroids, ctenochasmatoids and dsungaripteroids all show the derived state, to some degree, but it is most clearly developed in ctenochasmatids, for example in Gnathosaurus (Wellnhofer 1970) Ctenochasma (Wellnhofer 1978), and Pterodaustro (Bonaparte 1971, Sanchez 1973, Chiappe et al. 2000). C. atrox shows a similar marked ventral displacement of the quadrate articulation, associated with a distinctive downward curvature of the ventral outline of the skull anteroventral to the cheek region.

Mandibles: Each mandible consists of a long, narrow, deep tube, united anteriorly in a short symphysis (Fig. 1A, B). Notably, the mandibles are almost perfectly straight, in lateral aspect, as in some ctenochasmatoids such as Pterodactylus antiquus (Wellnhofer 1970) and Ctenochasma gracile (Wellnhofer 1978: fig. 5), but unlike most pterosaurs wherein the mandibles tend to exhibit some curvature especially toward the anterior or posterior end (Wellnhofer 1978: figs 2, 4-5).

The symphysis occupies only $30 \%$ of the total length of the lower jaw, essentially the plesiomorphic condition for pterodactyloids. The symphysial region broadens to form a spatula, similar to that of the rostrum, also strongly compressed dorsoventrally and with the posterior constriction, approximately level with the eighth dental alveolus, aligned with the point of maximum constriction of the skull. The mandibular spatula is much broader, however, its transverse width reaching almost twice that of the rostral spatula (Fig. 1D), a feature that has not, so far, been reported in any other pterosaur (Kellner \& Tomida 2000). Posterior to the spatula there is a marked step in the dorsal profile of the mandible between the sixth and seventh dental alveoli, corresponding exactly to the step in the rostrum and defining the posterior termination of the divergence between the jaw tips.
An unusual feature of the mandibles is that they appear, in lateral view, to achieve their maximum height toward the caudal end of the symphysis, and are somewhat lower, though of about even height, from this point to the articular region. Moreover, as Leonardi \& Borgomanero noted (1985), at this point the mandibles are distinctly deeper than the corresponding region of the rostrum, a proportion that is different from the typical condition in pterosaurs where the rostrum is usually the deeper of the two (e.g. Wellnhofer 1978).

According to Leonardi \& Borgomanero (1985) the angular is well developed and extends forwards to a point only a little short of the caudal end of the tooth row. The situation in other pterosaurs is not always clear because individual bones forming the mandible are often difficult to distinguish, but generally in pterodactyloids the angular is confined to the caudal end of the mandible and only ctenochasmatids such as Gnathosaurus (Wellnhofer 1970) and Ctenochas$m a$ (Wellnhofer 1978) show a condition that is more similar to that in $C$. atrox. According to Kellner \& Tomida (2000: 25) in the holotype of 'Anhanguera piscator' (= Coloborhynchus robustus) an exceptionally well preserved ornithocheirid that, unusually for pterosaurs, has distinctive bone sutures, the angular has an elongate process that extends forward at mid-height and is bounded ventrally by the dentary. If this unusual arrangement is typical of ornithocheirids then the construction of the mandible in this clade is markedly different from that in C. atrox.

Dentition: The dentition is not well preserved. More than half the teeth are missing and those present are rarely complete. In several cases the dental alveoli are poorly preserved and difficult to distinguish and in some putative positions the presence or absence of a particular alveolus cannot be determined. Leonardi \& Borgomanero (1985) reported 15 or 16 pairs of teeth in the rostrum, seven or, at most, eight in the premaxilla and eight in the maxilla, although their figures (ibid. fig. $2 \mathrm{a}-\mathrm{c}$ ) show six or seven pairs of teeth in the premaxilla and seven or eight in the maxilla. The total count described here is based on both sides of the skull.

The left premaxilla clearly contains seven tooth positions (Fig. 1A, C), although the seventh lies on the contact with the maxilla. The seventh position, represented by a fragmentary tooth, is evident on the anterior end of the right 
maxilla (Fig. 1B) and what is presumed to be the tenth position is also represented, on both left and right sides, by a fragmentary tooth. Consequently, what appears to be the eroded remains of an alveolus midway between the eighth and tenth positions on the left side presumably represents the ninth position. A poorly preserved alveolus in the left maxilla appears to represent the eleventh position, while positions twelve and thirteen are clearly evident on the same side. Continuing on the left side, two indistinct alveoli with approximately the same spacing as previous positions follow the thirteenth alveolus, but the dental margin on the right side is too poorly preserved to confirm this. In sum, the maxilla contains at least six and possibly as many as eight pairs of teeth, which, combined with the seven teeth in the premaxilla yields a minimum tooth count for the rostrum of 13 pairs, possibly ranging up to a maximum of 15 .

The anterior region of the mandibular symphysis contains six tooth positions, evident on both sides of the lower jaw, and represented by incomplete tooth crowns (Fig. 1B-C). Furthermore, the left mandible preserves positions seven to ten, represented by remains of alveoli, sometimes containing part of the tooth crown as, for example, in position seven. On the right side only position 10 , represented by an alveolus, is clearly distinguishable. Positions 11 and 12 are evident on the right side, but barely distinguishable on the left. An alveolus at position 13 contains the base of a tooth on the left side, but beyond this the dental margin is too poorly preserved to determine if further alveoli were present. On the right side, position 13 is barely distinguishable, but seems to be followed by the remains of a tiny alveolus, level with the anterior end of the nasoantorbital fenestra and representing position 14. In summary, there would appear to be at least 13 and possibly 14 pairs of teeth in the lower jaw.

A distinctive feature of $C$. atrox is the development of two different tooth morphologies. Teeth within the anterior part of the jaws are elongate and fang-like (Kellner \& Tomida 2000: fig. 64a; Fig. 1C), while those further to the rear are short and squat. Most of the anterior teeth are incomplete and have been restored so that they appear to be gently recurved and taper from the base of the crown to its tip, a morphology that is emphasised in the restorations (Leonardi \& Borgomanero 1985: fig 2c). However, virtually complete teeth in position two on the right and six on the left side of the rostrum, and positions five and six on the left side and three and four on the right side of the mandibular symphysis, together with other less complete examples, show that the anterior teeth where the jaw tips diverge, had pencil-shaped crowns of almost the same width throughout and only tapering at their tips (Fig. 2A). Moreover, they exhibit little or no antero-posterior curvature, except at the tips. It can be also deduced, from the morphology of the jaws, that the fang-like teeth had roots that were relatively short and less than half the length of the crown.

Teeth in the posterior half of the dentition are much shorter, with a crown height of only one to two times the basal diameter, and crowns that are triangular in outline, tapering from the base to the tip (Leonardi \& Borgomanero 1985: fig. 1a, b; Fig. 1C). Occasionally, the tips are recurved, otherwise the crowns are straight and the teeth stand perpendicular to the jaw.

Patterns of variation in tooth size and spacing, determined primarily on the basis of the anteroposterior diameter of the base of the tooth crown and the size of the gap between successive teeth (also determinable from dental alveoli where teeth are missing or not fully erupted) can provide important data for pterosaur systematics (Unwin \& Heinrich 1999, Fastnacht 2001) and this is certainly true for Cearadactylus atrox. In the rostrum the first four teeth are relatively large, with an increase in size from the first to third, while the fourth is smaller and similar in size to the first (Fig. 1C). The fifth tooth is remarkably small, approximately only one third the basal diameter of the third tooth, while the sixth and seventh teeth are slightly larger, though still small in comparison to the first four teeth. The remaining teeth (positions $8-15$ ) are larger than the preceding three, and their seems to a slight increase in size to the tenth tooth, which, although perhaps the largest in the maxilla, is still only approximately $75 \%$ the size of the fourth tooth (Fig. 1A, B). Beyond the tenth tooth there seems to be a decrease in size, the fourteenth and fifteenth (if correctly identified) being only slightly larger than the fifth to seventh. In terms of spacing, the first four teeth are closely packed and separated by less than a single crown base diameter. The remaining teeth are fairly evenly spaced, but the gap between them is much larger and approximately equivalent to twice the crown base diameter.

The size and spacing of the mandibular dentition complements that of the rostrum. Tooth numbers two, three and four are of similar size 
and markedly larger than the rest of the mandibular dentition (Fig. 1C) but, unlike the condition in the rostrum, the first tooth is considerably smaller than the succeeding three and less than half their basal diameter. Teeth in the fifth and sixth positions are much reduced compared to the preceding three, although to a lesser degree than the equivalent teeth in the rostrum, and are of a similar size to the first tooth. The remaining teeth (7-14) are somewhat larger than the fifth and sixth, but only reach, at most, approximately $75 \%$ the basal diameter of tooth pairs two to four (Fig. 1A, B). As in the rostrum, teeth in the midpart of this section (10-11), seem to be larger than preceding or succeeding teeth, the caudal-most, if correctly identified, being the smallest tooth in the entire mandible, but exact details (e.g. whether the increase or decrease in size is steady, or stepped) cannot be determined because of poor preservation. Tooth spacing closely matches that in the rostrum. The first four teeth are closely packed, and separated by less than a single crown base diameter. The remaining teeth are fairly evenly spaced and separated by at least twice the crown base diameter.

Patterns of tooth orientation are similar in the rostrum and the mandibles. In lateral aspect the first two pairs of teeth are partly procumbent: directed downward, but also somewhat forward at an angle of $25^{\circ}$ from the vertical. The remaining teeth are generally directed vertically, although several (fifth to seventh) may show a slight anterior inclination. In the mandibles, by contrast, the first four pairs of teeth are procumbent, the first markedly so, inclined at $30^{\circ}$ from the vertical. The fourth tooth is only slightly procumbent and the remaining teeth stand more or less vertical. A remarkable feature of the dentition, in both the upper and lower jaws, is that while most of the larger anterior teeth are procumbent (when viewed laterally), in anterior or dorsal view (Fig. 1D) these teeth show only a small degree of lateral divergence. Thus, the rostral teeth are directed downward and only slightly outward. The mandibular teeth show a somewhat greater degree of lateral divergence, so that their tips lie somewhat further out from the sagittal plane, but this can be partly attributed to the lateral curvature of these teeth. This is strikingly different from the situation in other pterosaurs that have dental "fish grabs" such as rhamphorhynchids (Wellnhofer 1975b: fig. 4b) and ornithocheirids (Fastnacht 2001: figs 3a, 5a) where the anterior fang-like teeth show a much greater degree of lateral divergence and recurva- ture. In Cearadactylus atrox the remaining teeth, in the upper and lower jaws, were directed vertically, with no lateral divergence.

Restoration of the skull of Cearadactylus atrox: A new restoration of the skull of this pterosaur, based directly on the left lateral aspect of the cranium and incorporating some features from the right side, is presented here (Fig. 2A). Although no attempt was made to reconstruct the posterodorsal region of the skull it seems likely that the general morphology of this region corresponded to that in other ctenochasmatids such as Gnathosaurus and Ctenochasma.

This restoration differs in some respects from previous restorations by Leonardi and Borgomanero (1985: fig. 2c; Fig. 2B), Wellnhofer (1987: fig. 1; Fig. 2C, refigured in Wellnhofer 1991a: 127, 1991b: 369, Martill 1993: fig. 5.2, reversed in Dalla Vecchia 1993: fig. 7) and Kellner \& Campos (2000: fig. 70a; Fig. 2D). Most importantly, all previous restorations show extrapolated portions of the premaxillae and the postorbital process of the jugal with a steeper inclination than is supported by the holotype. Moreover, Wellnhofer (1987) reconstructed the quadrate in a

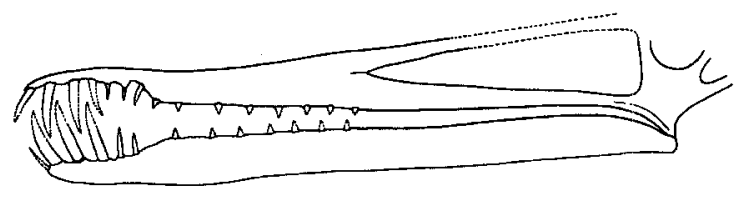

A
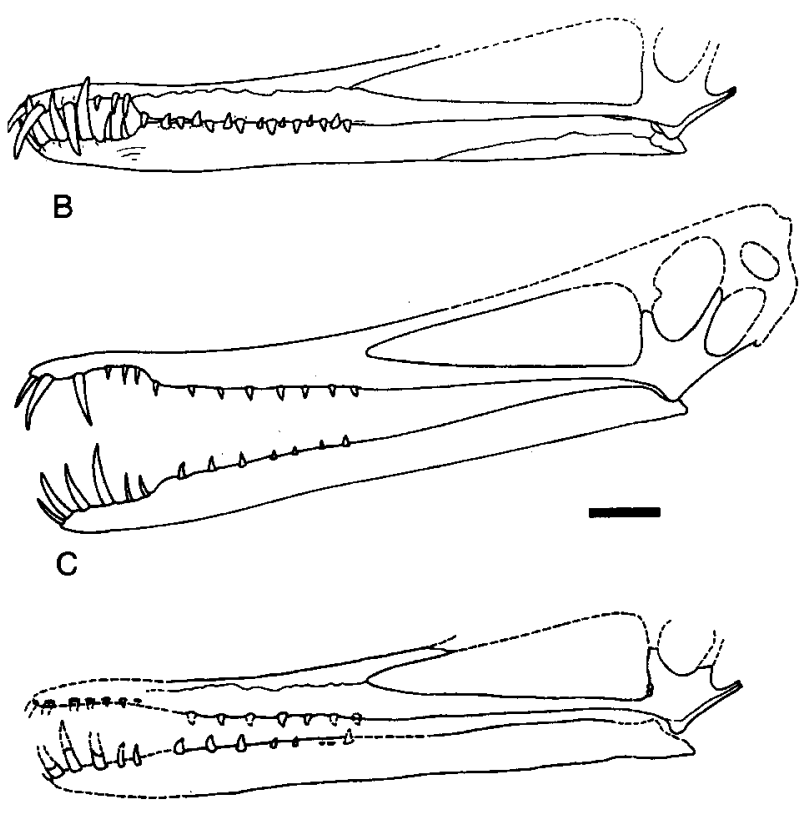

D

Fig. 2. Restorations of the cranium and mandible of Cearadactylus atrox. (A) this paper, (B) Leonardi \& Borgomanero (1985), (C) Wellnhofer (1987), and (D) Kellner \& Tomida (2000). Scale bar $=50 \mathrm{~mm}$. 
steeper orientation than evident in the fossil. These interpretations imply a relatively tall cranium, projecting well above the rostrum, with a subvertical lower temporal opening located largely behind the orbit, and a relatively tall, narrow, often pear-shaped orbital opening, with an acute ventral angle. Wellnhofer (1987) also attempted to reconstruct the entire cranium which, judging by the shape of the parietal region and the outline of the orbit, was based on Anhanguera santanae (Wellnhofer 1985), even though Leonardi \& Borgomanero (1985) and Wellnhofer (1991c) specifically excluded any relationship between C. atrox and the Ornithocheiridae, or synonymous equivalents such as the Anhangueridae. Available evidence suggests that $C$. atrox had a relatively low cranium, with a subcircular orbit that had a relatively wide base, and an inclined lower temporal opening that extended beneath the orbit.

Previous restorations of the dentition (Fig. 2B-D) are also inconsistent in some respects with the fossil material. Leonardi \& Borgomanero (1985: fig. 2c) appear to have omitted the fourth rostral tooth, while teeth at positions six and seven in the rostrum and five and six in the mandible appear to be relatively larger than they are in the fossil. Wellnhofer (1987: fig. 1; Fig. 2C) also appears to have omitted the fourth rostral tooth, the wide spacing of the teeth anterior to this position is quite unlike that in the fossil and the teeth in the posterior half of the dentition in both the upper and lower jaws are relatively tall and narrow, de-emphasising the morphological heterogeneity of the teeth evident in the holotype. Finally, in the restoration by Kellner \& Tomida (2000: fig. 70) the first four tooth pairs in the rostrum are shown as considerably smaller than pairs two to four in the mandible, although they appear to be of similar size in the fossil (Kellner \& Tomida 2000: fig. 64). This also means that the size difference between rostral tooth pairs five and six and the preceding three pairs is much smaller in the drawing than evident in the fossil.

\section{Is Cearadactylus atrox distinct from other pterosaurs?}

Two characters appear to distinguish Cearadactylus atrox from all other pterosaurs:

(1) The anterior expansion of the mandibular symphysis is almost twice as broad as the rostral expansion (Fig. 1D). Anterior expan- sion of the jaws, to form spatulae, occurs in gnathosaurines (Wellnhofer 1970, Dong 1982, Howse \& Milner 1995) and ornithocheirids (Unwin 2001), but in both these clades the spatulae are of similar widths.

(2) Extreme reduction in size of the fifth rostral tooth compared to the third rostral tooth. Size variation in the dentition is common in pterosaurs (e.g. Wellnhofer 1978, 1991a), but a sharp size difference between the third and fifth pairs of teeth in the rostrum, comparable to that evident in $C$. atrox, is only found in ornithocheirids (e.g. Fastnacht 2001). In the latter clade, however, the basal diameter of the third tooth does not reach more than 2.5 times the basal diameter of the fifth tooth (e.g. Fastnacht 2001: table 1). By contrast, in $C$. atrox the basal diameter of the third tooth is more than three times that of the fifth.

Evidence is presented below to show that C. atrox is a member of the Ctenochasmatidae. On this basis the following characters distinguish C. atrox from other ctenochasmatids and, although found in some non-ctenochasmatids, must have evolved independently in $C$. atrox:

(1) A groove extending along the dorsal contact of the premaxillae (Leonardi \& Borgomanero 1985). This structure has not been reported in any ctenochasmatid, although apparently it is present in an undescribed anhanguerid (Kellner \& Tomida 2000).

(2) At the posterior end of the symphysis the mandibles are deeper than the corresponding region of the rostrum (Leonardi \& Borgomanero 1985). In all other ctenochasmatids the rostrum is deeper than the mandibles at this point, as is generally the case in pterosaurs, although in a few highly derived taxa including Pteranodon (Bennett 2001), Nyctosaurus (Miller 1972) and Dsungaripterus (Young 1964, 1973) the reverse is true.

(3) Mandibles deepest at the posterior end of the symphysis. In most pterosaurs, including all ctenochasmatids, except for $C$. atrox, the mandibles are deepest at the articular end and taper anteriorly (Wellnhofer 1978: figs 2, 4-5). Exceptions include Pteranodon (Bennett 2001) and Nyctosaurus (Miller 1972), where the posterior end of the symphysis is much deeper than the mandibular rami.

(4) Jaw tips divaricate and containing seven pairs of rostral teeth and six pairs of mandib- 
ular teeth. Divaricate jaw tips are also present in the gnathosaurine, Huanhepterus (Dong 1982: fig. 1), but in this pterosaur the gap is filled with at least 21 pairs of rostral and 13 pairs of mandibular teeth. A toothfilled gap is found in several ornithocheirids, but in this clade it results from a gentle divergence of the anterior ends of the upper and lower jaws (e.g. Kellner \& Tomida 2000: fig. 11), so the divarication has a narrow, horizontal " $v$ " shape, rather than the slot-like outline evident in Cearadactylus atrox and Huanhepterus.

(5) Marked dimorphodonty, with abrupt change in tooth morphology in both upper and lower jaws. Other ctenochasmatids are homodont, often strikingly so (e.g. Broili 1924, 1936, Wellnhofer 1970, 1978, Buisonjé 1981). The only exception is Pterodaustro, but in this case tooth morphology varies between the upper and lower jaws (Bonaparte 1971, Sanchez 1973, Chiappe et al. 2000). Dimorphodonty is not uncommon in pterosaurs and the particular type of heterogeneity evident in $C$. atrox, with teeth that are long and fang-like anteriorly, but short and squat posteriorly, occurs in various groups including dimorphodontids (Owen 1870, Wild 1978), campylognathoidids (Wild 1978), rhamphorhynchids (Wellnhofer 1975b) and ornithocheirids (Kellner \& Tomida 2000). Usually, however, there is a gradual change in tooth shape from one morphology to the other, and the abrupt switch evident in C. atrox, otherwise only seen in dimorphodontids and Eudimorphodon, is unique among pterodactyloids.

(6) Short, squat, triangular teeth in the posterior half of the dentition. In other ctenochasmatids the teeth are thin and needle-like, even at the caudal end of the dentition, although teeth like those of $C$. atrox occur widely in other groups of pterosaurs (Wellnhofer 1978).

(7) No more than 15 pairs of teeth in the rostrum and 14 in the mandibles. The tooth count is greatly reduced in $C$. atrox compared to other ctenochasmatids, which have at least 25 pairs of teeth in the rostrum (Huanhepterus), often many more.

(8) Procumbent position of the first two pairs of teeth in the rostrum and the first three pairs in the mandibular symphysis. In ctenochasmatids the teeth in the anterior end of the tooth row are directed horizontally
(Gnathosaurus, Plataleorhynchus, Ctenochas$m a$ ), or vertically (Huanhepterus, Pterodaustro). C. atrox is distinguished by its obliquely procumbent teeth, although a similar arrangement is observed in several ornithocheiroids (e.g. Anhanguera, Coloborhynchus).

(9) "High cheek". The base of the orbit between the lacrimal and postorbital processes of the jugal is partially filled by a bony lamina. This type of development occurs in other pterosaurs, notably most ornithocheiroids (e.g. Wellnhofer 1985: figs 3, 32), and Dsungaripterus (Young 1973), but is not present in ctenochasmatids, or other ctenochasmatoids.

Leonardi \& Borgomanero (1985: 75) presented diagnoses for the genus and for the species (see also Wellnhofer 1991b: 368), but as only one species was described these diagnoses can be combined (see also Wellnhofer 1991b), yielding sixteen distinct characters. Those not already mentioned above are discussed here approximately in the order that they were presented in the original paper:

"Large pterosaurian, but not a giant one (wing span about $4 \mathrm{~m}$ in the adult)". Size is not diagnostic for pterosaurs. Within a single species osteologically mature individuals can exhibit a large size range (e.g. Bennett 1993). Moreover, individuals of various species including toothed forms such as Anhanguera santanae, that are generally similar to $C$. atrox, have dimensions that are approximately the same as those of $C$. atrox (see also Kellner \& Tomida 2000: 111).

"[P]reyer" [= predator]. Not diagnostic (Kellner \& Tomida 2000). Most, if not all known pterosaurs, including ctenochasmatids, were predators (Wellnhofer 1991a).

"[S]kull long and low". Not diagnostic (Kellner \& Tomida 2000). Most pterodactyloids including all ctenochasmatoids, all ornithocheiroids and some azhdarchoids had long low skulls (Wellnhofer 1978, 1987, 1991b, Unwin \& Lü 1997).

"[G]eneral outline, in zenithal view, elongated birsoyd, with rostral end spatulated". Not diagnostic. In dorsal view all gnathosaurines (Wellnhofer 1970, Dong 1982, Howse \& Milner 1995) and some ornithocheiroids (Campos \& Kellner 1985, Wellnhofer 1985, 1987, 1991c, Kellner \& Tomida 2000, Fastnacht 2001) have skulls that exhibit the same general shape and also have spatulate anterior terminations to the jaws. 
"[A]lveolar borders of the of the premaxillary do not occlude with the jaw, leaving a wide gap". See discussion of divaricate jaw tips above.

"Premaxillary dentition very long and, except the most anterior teeth, obliquously outward stretched and curved". See discussion of tooth orientation and dimorphodonty above.

"[MJaxillary teeth spaced, short, conical, not very sharp and slightly stretched backward". See discussion of maxillary teeth above.

"All teeth alternate in the upper and inferior rows, so that they interfinger, while in the occlusion the lower ones lie external to the maxillary, and the upper ones lie external to the mandible". Not diagnostic. This occurs in many pterosaurs including most ctenochasmatids (Wellnhofer 1978).

"Antorbital fenestra (fused with the external naris) very long, with the posterior border forming an angle of about 90 degrees with the lower border". The nasoantorbital fenestra shown in the restoration (Fig. 2A) has a slightly greater length to height ratio $(1: 4.24)$ than other ctenochasmatids such as Pterodaustro (1:4.0) and Gnathosaurus (1:3.69), but uncertainty regarding the exact shape of the nasoantorbital fenestra means that this distinction is unreliable. The shape of this fenestra is the same as that in many pterodactyloids including all ctenochasmatoids (Wellnhofer 1970, 1978, 1991b).

"The antero-superior border of the antorbital fenestra is formed only by the premaxilla". Exclusion of the maxilla from the upper margin of the nasoantorbital fenestra is unusual in pterosaurs, but seems to occur in the ctenochasmatid Pterodaustro (Chiappe et al. 2000) and the ctenochasmatoid Cycnorhamphus (e.g. Wellnhofer 1978).

"Long groove along almost the entire length of the suture between premaxillae". See discussion above.

"Sagittal crest lacking, at least until the first third part of the antorbital opening". Not diagnostic. Many pterosaurs do not have a cranial sagittal crest (Wellnhofer 1978, 1991a).

"Base of the temporal region (between the quadrate and the posterior border of the antorbital fenestra) narrow and funnel shaped". Not diagnostic as formulated here, moreover the construction of this region in C. atrox is similar to that in most non-ornithocheiroid pterodactyloids (e.g. Wellnhofer 1978), although the morphology of the jugal is distinct from that of other ctenochasmatids (see above).
"Length of the symphysis equal to nearly one third of the mandible". Not diagnostic (Kellner \& Tomida 2000). Symphyses of similar length are found in various pterodactyloids including the ctenochasmatid Gnathosaurus macrurus (Howse \& Milner 1995: fig. 1).

"Mandibular ramus deeper than the rostral portion of the skull'. See discussion above.

"Anterior end of the mandible spatulated". Not diagnostic in this formulation. All other gnathosaurines and some ornithocheirids (Anhanguera, Coloborhynchus) also have a mandibular symphysis with a spatulate anterior termination.

In summary, Cearadactylus atrox can be clearly distinguished from all other pterosaurs by characters of the jaws and dentition, and from other ctenochasmatids by a further nine cranial and dental characters.

\section{'Cearadactylus? ligabuei'}

Dalla Vecchia (1993) proposed three characters that apparently support a close relationship between 'Cearadactylus? ligabuei' (Fig. 3) and Cearadactylus atrox.

(1) "alveolar margin of the anterior part of the maxilla is concave, leaving, in the occlusion with the lower jaw the gap cited by Leonardi and Borgomanero". An unusual feature of the rostrum of 'Cearadactylus? ligabuei' (CSRL 12962/12713) is a short recessed section of the dental margin of the maxilla, corresponding to tooth positions four to eight, that in lateral view exposes the palatal surface of the jaw (Dalla Vecchia 1993: fig. 1a, b; Fig. 3A). Dalla Vecchia suggested that this structure was homologous with the divaricate jaw tips evident in $C$. atrox, but the argument is not convincing. Although the maxilla is slightly recessed, the ventral outline of the skull continues in a straight line from the tip of the rostrum posteriorly, at least to a point level with the nasoantorbital fenestra, and there is no "step" as in C. atrox. Moreover, in the latter species the divarication is confined to the premaxillae and involves tooth pairs one to seven. Furthermore, it would seem from the construction of the rostrum in 'Cearadactylus? ligabuei' that, at full occlusion, there would be little or no gap between the premaxillae and the maxillae on the one hand, and the mandibular symphysis on the other. Finally, exactly the same struc- 

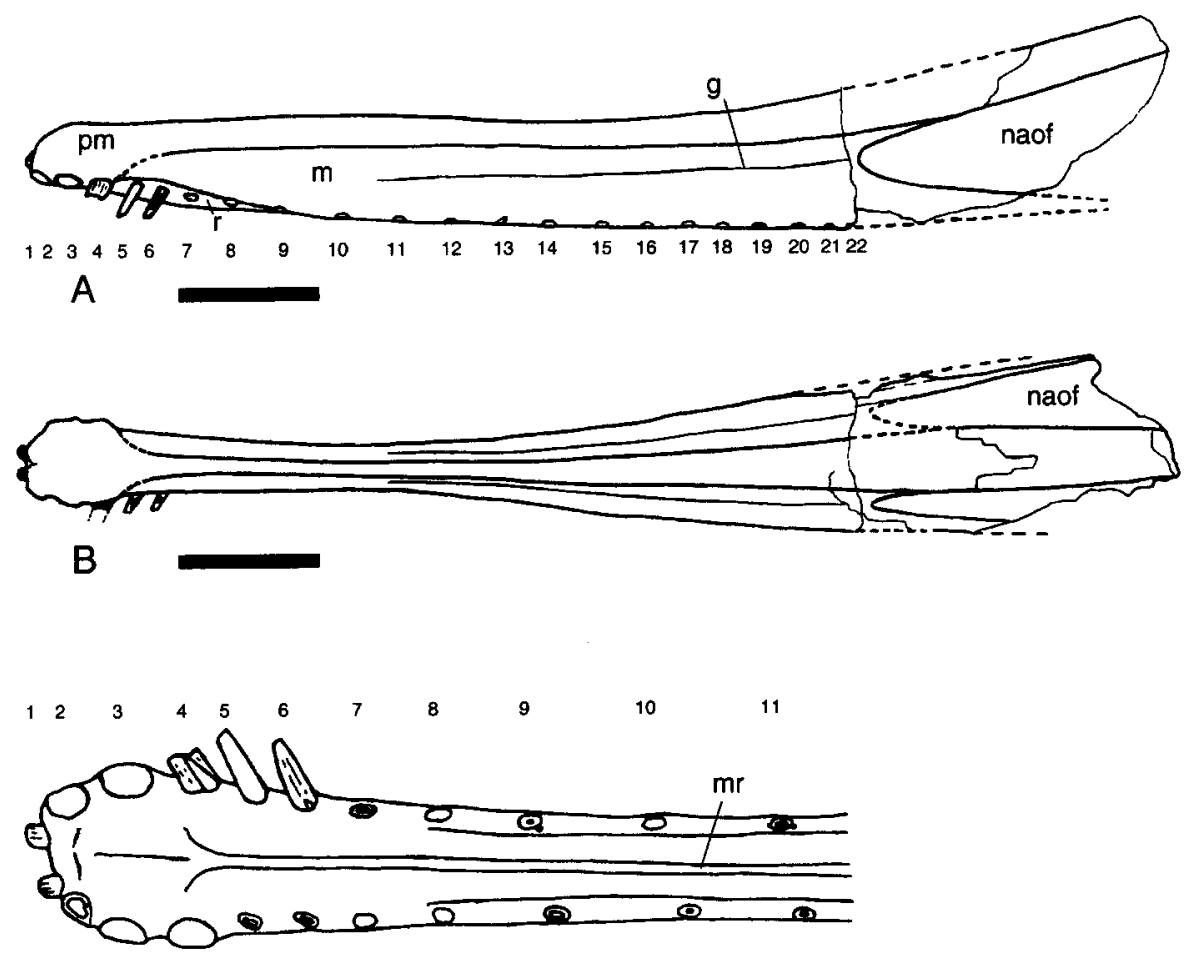

Fig. 3. 'Cearadactylus? ligabuei' (CSRL 12962/12713) from the Romualdo Member, Santana Formation, of Brazil. Cranium in (A) left lateral and (B) dorsal view. Anterior end of rostrum in ventral view (C) and left jugal in lateral view (D). Tooth with replacement tooth (E), from position six, left side of the rostrum. Redrawn from Dalla Vecchia (1993). Abbreviations as for Fig. 1 except: in, infilling of posteroventral angle of nasopreorbital fenestra; mr, median ridge; $\mathbf{r}$, recess. Scale bar $=50 \mathrm{~mm}(A$, B), $10 \mathrm{~mm}(\mathrm{C}, \mathrm{D}), 5 \mathrm{~mm}(\mathrm{E})$.

ture, a recession of the dental margin extending from tooth pairs five to eight, occurs in the rostrum of Coloborhynchus robustus (Fastnacht 2001, fig. 2a, b).

(2) "The premaxillary teeth are considerably larger than the other ones." As Dalla Vecchia noted (1993) in his discussion of this character, there is a marked disparity in size between the teeth in the anterior and posterior sections of the premaxilla of $C$. atrox, that is similar to the condition in 'Cearadactylus? ligabuei'. At a general level this is correct, but the two species differ in some important details. In 'Cearadactylus? ligabuei' there is a steady increase in tooth size from the first to the fourth pair, while tooth pairs five to seven are of approximately the same size and slightly larger than tooth pair one (Fig. 3A, C). By contrast, in C. atrox the third tooth is larger than the fourth, tooth pairs five to seven are more uneven in size and, more im-

portantly, considerably smaller than any of the first four pairs of teeth. Moreover, as Dalla Vecchia (1993) also noted, the premaxilla of 'Cearadactylus? ligabuei' contains four teeth (Fig. 3A), as is typical for pterosaurs, but in C. atrox it has seven tooth positions, a highly unusual character otherwise only found in ctenochasmatids.

(3) "The skull is long and low, without a sagittal crest on the snout and its anterior end is spatulate." These four characters do not unite 'Cearadactylus? ligabuei' and C. atrox. A long, low skull occurs in various ctenochasmatids (Ctenochasma, Gnathosaurus, Plataleorhynchus) and also in many ornithocheirids (Anhanguera, Coloborhynchus, Ornithocheirus). Aside from the problems associated with 'absence' characters, absence of a sagittal crest on the snout is common in pterosaurs and plesiomorphic for Pterodactyloidea. A spatulate anterior end of the ros- 
trum is found in all gnathosaurines and also in some ornithocheirids (Anhanguera, Coloborhynchus).

This analysis thus confirms the conclusion reached by Kellner and Tomida (2000), that none of the three characters proposed by Dalla Vecchia (1993) supports a close relationship between 'Cearadactylus? ligabuei' and C. atrox. This also seems to be the case with regard to the 11 characters recognised here as diagnostic for C. atrox and thus potential synapomorphies of Cearadactylus. The relative size of the mandibular spatula is unknown in 'Cearadactylus? ligabuei', but while the fifth rostral tooth is smaller than the third, it is still considerably more than half the basal diameter of the third tooth (Fig. 3C), rather than less than one third, as in C. atrox. There is no groove extending along the dorsal margin of the rostrum in 'Cearadactylus? ligabuei', and there is no distinct anterior divarication of the jaw tips or marked dental dimorphodonty. Furthermore 'Cearadactylus? ligabuei' has 22 pairs of teeth located between the tip of the rostrum and the anterior termination of the nasoantorbital fenestra, compared to just 13-15 pairs in C. atrox. Procumbent teeth are present in 'Cearadactylus? ligabuei', but this appears to affect at least tooth pairs one to six (Fig. 3A), rather than just the first two pairs as in $C$. atrox. More significantly, the teeth of 'Cearadactylus? ligabuei' show a marked lateral divergence affecting at least the first six pairs of teeth (Fig. 3B), which is quite unlike the subvertical arrangement of the dentition in $C$. atrox. One character that these species do share in common is the development of a high cheek (cf. Figs 1A, 3D), but this feature also occurs in other pterosaurs including most ornithocheiroids and some dsungaripterids.

'Cearadactylus? ligabuei' also exhibits the primitive state for all synapomorphies of the Gnathosaurinae or the Ctenochasmatidae, casting further doubt on the likelihood of any close relationship with $C$. atrox. Thus, although 'Cearadactylus? ligabuei' has a rostral spatula, it is not dorsoventrally compressed as in gnathosaurines, but is almost as deep as it is wide, as in ornithocheirids. Unlike ctenochasmatids, the rostrum anterior to the nasoantorbital fenestra forms less than half the total reconstructed length of the skull, and its anterior end is not dorsoventrally compressed and rounded. There are fewer than 25 teeth per side in the rostrum, although this could be argued to be a derived character shared with C. atrox and Huanhepterus within the Gnathosaurinae, and there are only four pairs of teeth in the maxillae (Fig. 3A). The teeth do not project horizontally from the dental border in the anterior part of the dentition which, again, could be argued to be a character shared with Huanhepterus and $C$. atrox, except that, unlike the latter two taxa, in 'Cearadactylus? ligabuei' teeth in positions two to seven are directed ventrolaterally rather than vertically. Furthermore, the teeth taper from the base to the tip of the crown (Fig. 3E), rather than having a long cylindrical crown of even width and a short tapering distal tip as in ctenochasmatids. In the restoration by Dalla Vecchia (1993: fig. 7a), the posterodorsally directed posterior continuation of the premaxillae and the steeply oriented postorbital process of the jugal (Fig. 3D) all suggest that 'Cearadactylus? ligabuei' had a relatively high cranium, unlike the low cranium and associated characters typical of ctenochasmatoids. Finally, the maxilla forms part of the dorsal border of the nasoantorbital fenestra, unlike the condition in Cearadactylus atrox and some other ctenochasmatoids (see above) where it is entirely excluded from the dorsal border.

Comparisons of 'Cearadactylus? ligabuei' with other pterosaurs, reveal a number of derived characters shared with ornithocheirids. The expanded anterior end of the rostrum is remarkably similar to that of Anhanguera blittersdorffi (Campos \& Kellner 1985: fig. 1) including the gradual narrowing of the rostrum posteriorly to a point between the tenth and eleventh tooth positions, unlike Cearadactylus atrox where the rostrum is narrowest between tooth positions seven and eight. Moreover, the patterns of size, spacing and orientation of the teeth in 'Cearadactylus? ligabuei' closely match those of Anhanguera blittersdorffi (Campos \& Kellner 1985: fig. 1), Anhanguera santanae (Wellnhofer 1991c: fig. 2) and Coloborhynchus robustus (Kellner \& Tomida 2000: figs 4, 5, Fastnacht 2001: figs 2, 3), and also correspond to one of the derived character states supporting the Ornithocheiridae (Unwin 2001). In addition, 'Cearadactylus? ligabuei' also exhibits a rounded bony infilling of the angle between the lacrimal and maxillary processes of the jugal (Fig. 3D), and a relatively narrow, deep ventral margin of the orbit (Dalla Vecchia 1993: fig. 7). Both of these features are typical of ornithocheirids, although not absolutely confined to this clade. The palatal surface of the rostrum of 'Cearadactylus? ligabuei' bears a broad, deep median ridge lateral to which the 
palate is transversely concave (Dalla Vecchia 1993: fig. 2), similar to the condition in ornithocheirids (Wellnhofer 1985, 1991c), but unlike that in ctenochasmatids, where the median ridge is small and sharp and bordered by wide flat palatal shelves (Howse \& Milner 1995). In many other respects, including tooth morphology, the shape of the nasoantorbital fenestra and a prominent groove originating from the anterior apex of the nasoantorbital fenestra, 'Cearadactylus? ligabuei' compares closely with Anhanguera santanae (Wellnhofer 1985, 1991c) and other ornithocheirids, although these characters also occur in other pterodactyloids. The absence of a sagittal crest on the rostrum does not exclude 'Cearadactylus? ligabuei' from the Ornithocheiridae, because this putatively secondary sexual character is highly variable and lacking in some taxa that clearly belong within this clade including Brasileodactylus araripensis (Kellner 1984), Coloborhynchus sedgwicki (Unwin 2001) and a new ornithocheirid from the Crato Formation of Brazil (Frey \& Martill in press).

In conclusion, 'Cearadactylus? ligabuei' does not share any unique characters in common with Cearadactylus atrox and there are no grounds for retaining this species within Cearadactylus. There is some weak evidence in favour of a relationship with gnathosaurines, but this is strongly contradicted by the absence of key apomorphies of the Gnathosaurinae and the Ctenochasmatidae. By contrast, 'Cearadactylus? ligabuei' exhibits a key apomorphy of the Ornithocheiridae and shows many similarities to crania currently assigned to various species of Anhanguera. For the present, this species is tentatively assigned to $A n$ hanguera as Anhanguera? ligabuei, with the proviso that the taxonomic validity and relationships of this pterosaur require further study.

\section{The relationships of Cearadactylus atrox to other pterosaurs}

Methods and materials: A two stage phylogenetic analysis was carried out to establish the relationships of Cearadactylus atrox to other pterosaurs. In the first stage, $C$. atrox was added to a data set of 20 taxa, including all main clades of pterosaurs, and 67 characters, nearly all binary and evenly split between cranial and postcranial morphology (Unwin in press). In the original analysis (Unwin in press) the Ctenochasmatidae was treated as a terminal taxon, consequently, in this study, apomorphies of this clade (listed in the diagnosis, above) were incorporated into the main data set in order to test the hypothesis (Unwin 1992, 2001, Unwin et al. 2000) that Cearadactylus is more closely related to the Ctenochasmatidae than to any other taxon.

The data matrix (see Unwin, in press) was analysed using PAUP 3.1.1 (Swofford, 1993), with the branch and bound search option, and addition sequence 'furthest'. Runs were executed using both ACCTRAN and DELTRAN settings. Multiple state characters were always treated as unordered. Three different outgroups were used: basal ornithodirans, basal archosaurs and prolacertiforms. Pterosaur skeletal anatomy is so derived, however, that selection of any particular group had no effect on character polarity because, in almost all cases, the plesiomorphic condition is the same in each group. The analysis generated six trees, differing only in the position of Pterodactylus and Lonchodectes with respect to the Ctenochasmatidae + Cearadactylus, and the relationship of the Dsungaripteroidea to the Ctenochasmatoidea or the Azhdarchoidea. One of the six trees, which has the same topology as the strict consensus tree, is shown in Fig. 4A to-

Table 1

List of characters used in the analysis of species relationships within the Ctenochasmatidae.

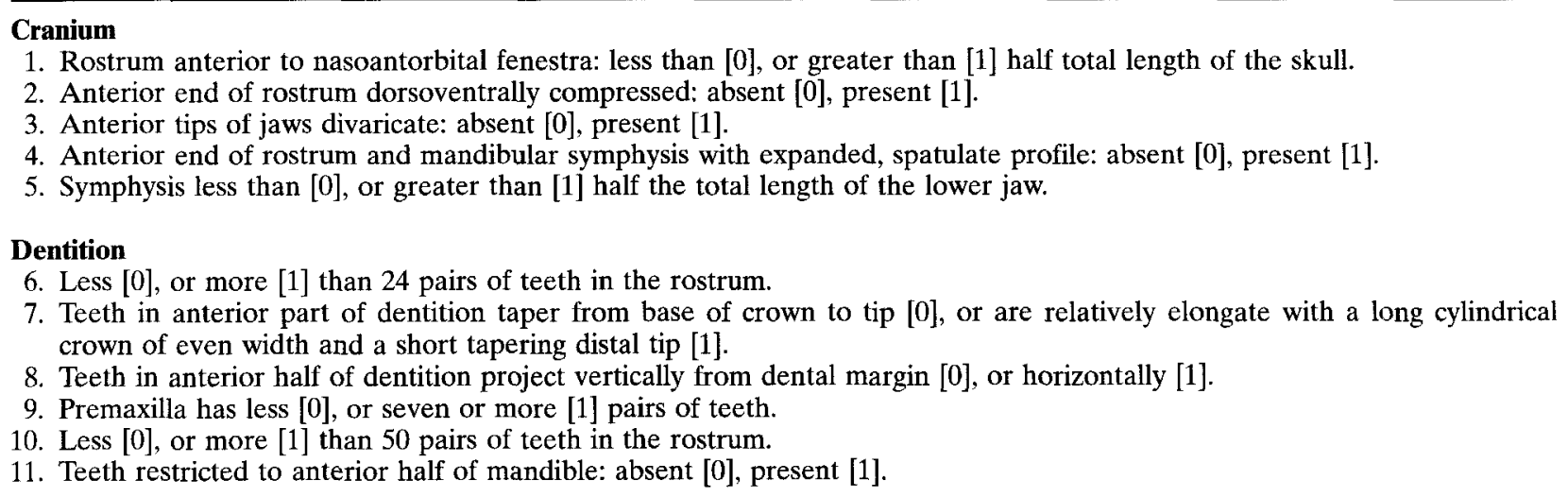



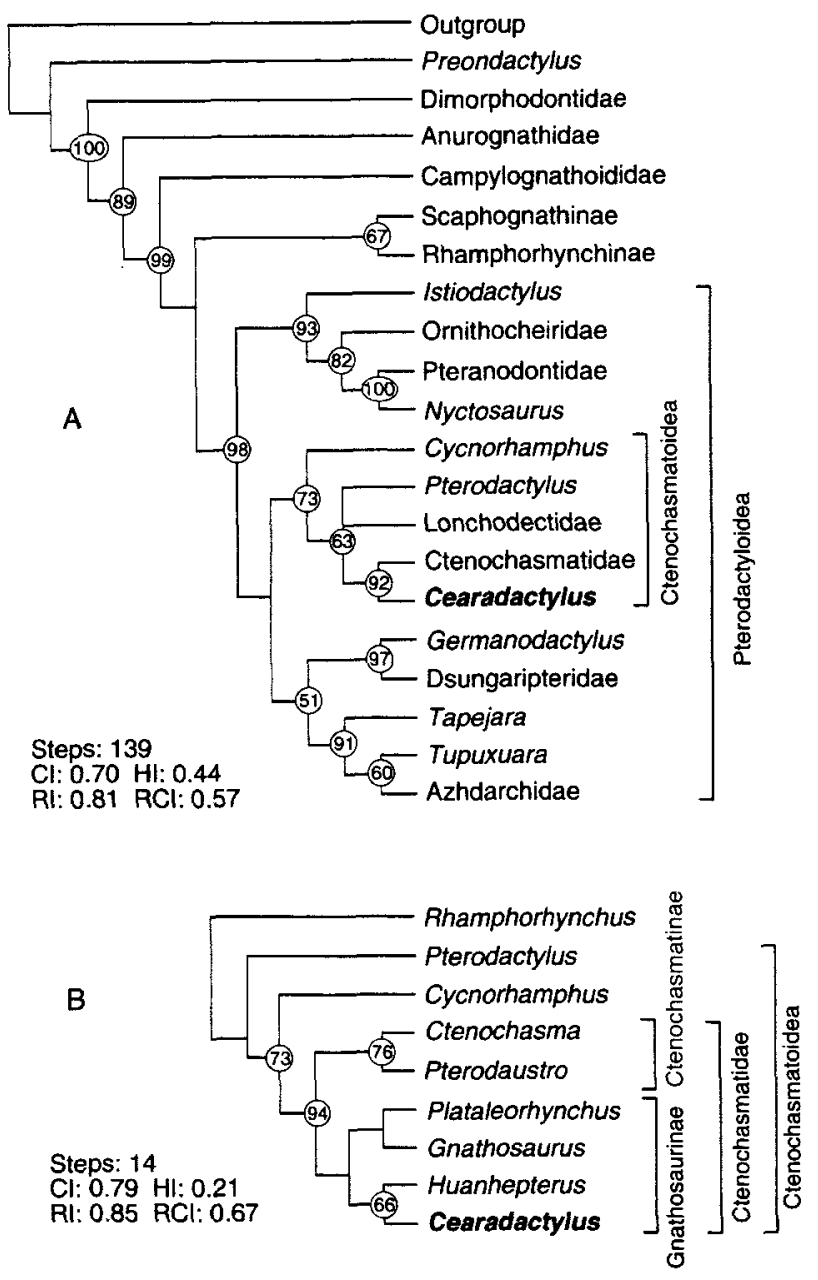

Fig. 4. Cladograms showing (A) phylogenetic relationships of Cearadactylus to other major clades of pterosaurs and (B) to other species of the Ctenochasmatidae. Bootstrap values shown at nodes. Abbreviations: CI, consistency index; HI, homoplasy index; RCI, Rescaled consistency index; RI, Retention index.

gether with bootstrap values (1000 replicates) and other statistical data.

The second stage of the analysis focused on a data set consisting of 11 characters, five concerning the cranium and six describing the dentition (Table 1), and nine terminal taxa (Table 2): six ctenochasmatids, two ctenochasmatoids and an outgroup taxon (Rhamphorhynchus). The data matrix (Table 2) is $98 \%$ complete (only two missing entries) and all characters are binary. The data matrix was analysed in exactly the same way as for the first stage and resulted in a single most parsimonious tree (Fig. 4B).

Results and discussion: The results of the first analysis confirm that Cearadactylus is a pterodactyloid (presence of a nasoantorbital fenestra) and support a relationship within the Ctenochasmatoidea (quadrate oriented in a subhorizontal position). Both analyses indicate strong support for the assignment of Cearadactylus to the Ctenochasmatidae (Cearadactylus exhibits the derived state for characters 1,2, 7 and 9, see Table 2). Within the Ctenochasmatidae Cearadactylus shares one unambiguous synapomorphy with gnathosaurines (rostrum with rounded, dorsoventrally compressed, spatulate, anterior expansion), but no characters in common with ctenochasmatines. Leonardi \& Borgomanero (1985) doubted that Cearadactylus shared a close relationship with Gnathosaurus and Huanhepterus because it lacked a sagittal crest on the rostrum. This structure is highly variable in its distribution in pterosaurs, even within a single species (e.g. Germanodactylus rhamphastinus), and so its phylogenetic significance is uncertain. It should also be noted that other ctenochasmatids including Ctenochasma gracile and Pterodaustro guinazui also lack bony sagittal crests.

Huanhepterus and Cearadactylus form a subclade within the Gnathosaurinae, united by one unambiguous synapomorphy ( anterior tips of jaws divaricate (see also Leonardi \& Borgomanero 1985)), one ambiguous synapomorphy (teeth restricted to anterior half of mandible) which also appears in Cycnorhamphus, and one character reversal (teeth vertically oriented).

An alternative possibility is that Cearadactylus shares a close relationship with the Ornithocheir-

Table 2

Distribution of character states $(0,1)$ among the terminal taxa used in the analysis of species relationships within the Ctenochasmatidae. Uncertainty because of incomplete preservation is indicated by '?'.

\begin{tabular}{|c|c|c|c|c|c|c|c|c|c|c|c|}
\hline & 1 & 2 & 3 & 4 & 5 & 6 & 7 & 8 & 9 & 10 & 11 \\
\hline Rhamphorhynchus muensteri & 0 & 0 & 0 & 0 & 0 & 0 & 0 & 0 & 0 & 0 & 0 \\
\hline Cycnorhamphus suevicus & 0 & 1 & 0 & 0 & 0 & 0 & 0 & 0 & 0 & 0 & 1 \\
\hline Pterodactylus kochi & 0 & 0 & 0 & 0 & 0 & 0 & 0 & 0 & 0 & 0 & 0 \\
\hline Gnathosaurus subulatus & 1 & 1 & 0 & 1 & 0 & 1 & 1 & 1 & 1 & 0 & 0 \\
\hline Plataleorhynchus streptophorodon & $?$ & 1 & 0 & 1 & $?$ & 1 & 1 & 1 & 1 & 0 & 0 \\
\hline Huanhepterus quingyangensis & 1 & 1 & 1 & 1 & 0 & 1 & 1 & 0 & 1 & 0 & 1 \\
\hline Cearadactylus atrox & 1 & 1 & 1 & 1 & 0 & 0 & 1 & 0 & 1 & 0 & 1 \\
\hline Ctenochasma gracile & 1 & 1 & 0 & 0 & 1 & 1 & 1 & 1 & 1 & 1 & 0 \\
\hline Pterodaustro guinazui & 1 & 1 & 0 & 0 & 1 & 1 & 1 & 0 & 1 & 1 & 0 \\
\hline
\end{tabular}


idae (Kellner \& Tomida 2000), or may even belong within this family. In this analysis Cearadactylus was found to share one putative synapomorphy with the Ornithocheiroidea ("high cheek") and two with the Ornithocheiridae (expanded anterior end of the rostrum, relatively large size of the first three pairs of teeth in the rostrum). The development of a high cheek is not confined to ornithocheiroids (also present in Dsungaripterus), so this is not an unambiguous synapomorphy. Comparisons between ornithocheirids such as Anhanguera (Campos \& Kellner 1985, Wellnhofer 1991c) and Coloborhynchus (Kellner \& Tomida 2000, Fastnacht 2001) with Cearadactylus show that the rostral and mandibular spatulae of the latter are quite different in shape from those of the former. They have an oval outline, are widest in the mid part of the spatula, terminate just caudal to the seventh tooth position in the rostrum and are strongly dorsoventrally compressed. By contrast, the spatulae in ornithocheirids are highly asymmetrical anteroposteriorly (e.g. Fastnacht 2001: figs 2 b, $3 c$ ), widest at or near the anterior tip of the jaw and taper to a point between the ninth and tenth tooth positions. In addition, they are usually as deep, measured in the sagittal plane, as they are wide, in order to accommodate the long roots of the anterior fang-like teeth.

Variation in tooth size along the jaw in ornithocheirids is clearly similar to that of Cearadactylus, but, in the latter, the fifth to seventh rostral teeth are far smaller than the third tooth, and of similar size to one another. In ornithocheirids (e.g. Fastnacht 2001), the fifth tooth is approximately half the diameter of the third, but beyond this position there is a steady increase in tooth size up to the ninth or tenth tooth. Moreover, in the lower jaw of ornithocheirids there is a steady increase in tooth size from the first to the third position, the fourth tooth is smaller than the first and about two thirds the size of the third, after which there is a steady increase in size from the fifth to the ninth tooth (Kellner \& Tomida 2000). This is distinct from Cearadactylus where pairs two to four are of similar size and much larger than the first pair, the fifth pair is much less than half the diameter of the third pair and the remaining eight pairs are of similar size. In addition, the anterior teeth of Cearadactylus have relatively short roots compared to crown length, as in ctenochasmatids (e.g. Gnathosaurus macrurus Howse \& Milner 1995, Ctenochasma porocristata Buisonjé 1981: figs 1b, 2a) and a different shape from that of ornitho- cheirids where the roots are long and often of similar length to the crown (e.g. Fastnacht 2001: fig. 4).

If Cearadactylus is an ornithocheirid, all the synapomorphies that it shares with Huanhepterus, gnathosaurines and ctenochasmatids, must have evolved independently in this pterosaur because Istiodactylus, which is basal to ornithocheirids, within the Ornithocheiroidea (Unwin 1995, in press, Unwin \& Lü 1997, Unwin et al. 2000), does not have these synapomorphies. For the same reason, characters such as the absence of a concave posterior margin of the nasoantorbital fenestra, absence of a distinct vascular groove extending forward from the anterior tip of the nasoantorbital fenestra, and the presence of "straight" mandibles, all present in Cearadactylus, but representing the plesiomorphic condition within the Ornithocheiroidea, must be character reversals in Cearadactylus, because all other ornithocheiroids exhibit the derived condition. Thus, within the context of the phylogenetic analyses conducted here, only five additional character state changes are needed to accommodate Cearadactylus within the Gnathosaurinae, compared to 14 changes if it is an ornithocheirid. At present, therefore, character state distributions strongly support the inclusion of Cearadactylus within the Gnathosaurinae, as a sister taxon to Huanhepterus.

\section{Cearadactylus and its possible association with other pterosaur material from the Santana Formation}

Considering the diagnostic features of Cearadactylus atrox listed above it would seem that none of the other pterosaur specimens so far described from the Santana Formation, that include a rostrum or mandibles (Kellner, 1984, 1989, Campos \& Kellner 1985, 1997, Wellnhofer 1985, 1987, 1991b, c, Kellner \& Campos 1988, 1994, Kellner \& Tomida 2000) can be assigned to Cearadactylus. This still leaves a number of specimens that are not directly comparable with C. atrox because they lack the cranium and lower jaws. If it is accepted that Cearadactylus is a ctenochasmatid then many of these remaining specimens (Price 1971, Wellnhofer 1977, 1985, 1991b, c, Leonardi \& Borgomanero 1987, Wellnhofer et al. 1983, Dalla Vecchia \& Ligabue 1993) can be excluded from consideration because features such as the twisted deltopectoral crest of the humerus (Padian 1984, 1986, Ben- 
nett 1989), diameter of the shaft of the radius less than half that of the ulna (Kellner \& Tomida 2000), details of the wrist bones (Unwin 1995, in press) and the morphology of the proximal end of the wing-phalanx 1 (Unwin unpub. data), show that they are ornithocheiroids. Interestingly, this includes the holotype and only known specimens of Araripesaurus castilhoi (DGM 529R) and Araripedactylus dehmi (BSP 1975 I 166) thus Cearadactylus atrox is not a junior synonym of either of these species.

Four of the five remaining specimens only known from postcrania (Campos et al. 1984, Wellnhofer 1985 [BSP 1980 I 121, BSP 1982 I 93], Kellner 1995 [DNPM CD-R-019]), might belong to $C$. atrox, but there is no positive evidence to support this referral because they all exhibit characters typical of most non-ornithocheiroid pterodactyloids and it is equally possible that they belong to Tapejara (as Kellner has proposed for DNPM CD-R-019), or Tupuxuara, the two non-ornithocheiroid taxa described so far from the Santana Formation.

There is, however, some indirect evidence to support the idea that the fifth specimen, two associated cervical vertebrae (Buisonjé 1980), could be referred to Cearadactylus. The vertebrae (UMGI M4895, Fig. 5), probably the third and fourth cervicals, possibly the fourth and fifth, were described by Buisonjé (1980) under the name of 'Santanadactylus brasilensis', but were not found in association with the holotype of this species, an incomplete scapulocoracoid and proximal end of the humerus (Buisonjé 1980: figs 2-4), representing an indeterminate ornithocheiroid, and are presently treated as Pterodactyloidea indet. (Kellner \& Tomida 2000). Low, elongate cervical vertebrae occur in two distinct pterodactyloid clades: ctenochasmatoids and azhdarchoids (Kellner 1995b, Unwin 1995 , in press, Unwin \& Lü 1997). In the Santana Formation, azhdarchoids are represented by Tupuxuara, which has short, relatively blocky cervical vertebrae (e.g. IMCF 1052) and Tapejara, a relatively small pterosaur that has low, elongate vertebrae (Wellnhofer \& Kellner 1991), approximately twice as long as their minimum width, although they are proportionally shorter than those described by Buisonjé (1980) which have a length to minimum width ratio of $1: 2.84$. A putative azhdarchid has been reported from the Crato Formation (Martill \& Frey 1999), which, if confirmed, would indicate that this clade probably existed in South America during the deposition of the Santana Formation. This specimen may prove, however, to be a tapejarid, but in any case the cervicals described by Buisonjé (1980) are proportionately shorter than those of true azhdarchids (width to length ratio of $>8$ ), have a distinct neural arch and centrum, unlike the condition in azhdarchids where these structures are merged into a single tube (Nesov 1984, Padian 1984, Howse 1986), pneumatic formina located on the lateral sides of the vertebral centrum and a low, but well developed neural crest, contrasting with the absence of these structures in azhdarchids (Nesov 1984, Howse 1986).

Cearadactylus is the only ctenochasmatoid known from the Santana Formation and it can be inferred from the presence of elongate cervical vertebrate in all other ctenochasmatids where the neck is preserved: Ctenochasma (Broili 1924, 1936, Wellnhofer 1970); Pterodaustro (Bonaparte 1970, Wellnhofer 1991a); and Huanhepterus
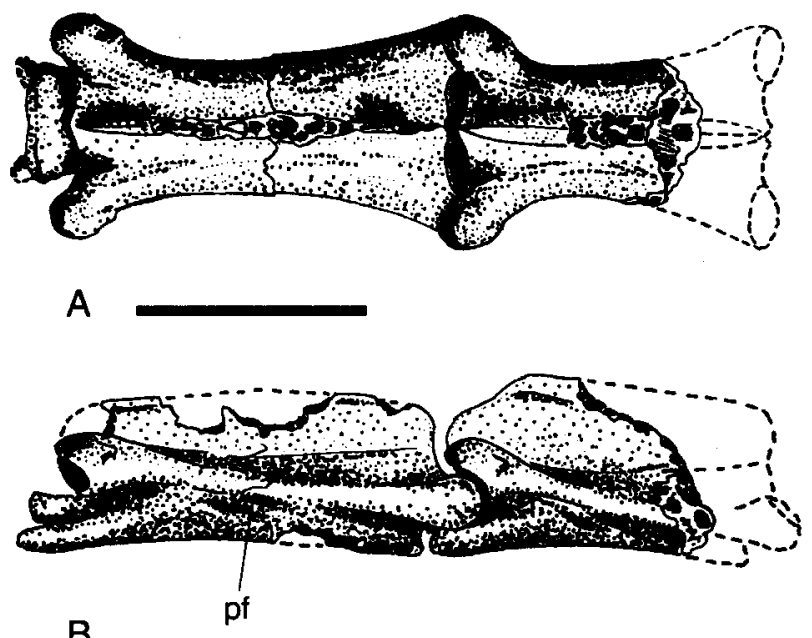

B

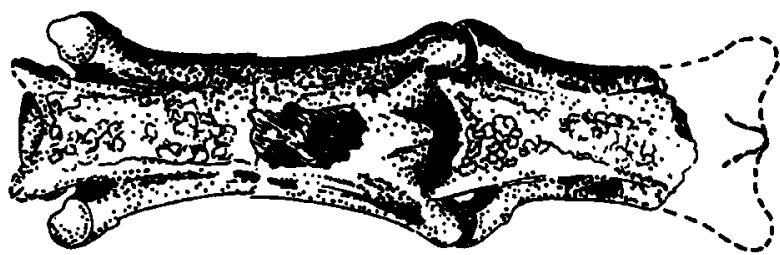

C

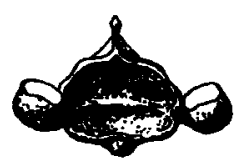

D

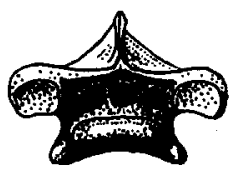

E

Fig. 5. Cervical vertebrae (GIUA M 4895) in (A) dorsal, (B) right lateral, (C) ventral, (D) anterior and (E) posterior views, from the Romualdo Member of the Santana Formation, Brazil, originally described by Buisonjé (1980) under the name 'Santanadactylus brasilensis', and tentatively assigned here to Cearadactylus. Redrawn from Buisonjé (1980). Abbreviations: pf, pneumatic foramen. Scale bar $=50 \mathrm{~mm}$. 
(Dong 1982) that it too probably had elongate cervicals. The cervicals described by Buisonjé (1980) have a maximum width across the zygapophyses of just over $50 \mathrm{~mm}$, which in comparison with pterosaurs known from more complete remains and with vertebrae of similar dimensions, indicates a wingspan in the region of $4 \mathrm{~m}$. This corresponds reasonably well with the likely size of the individual represented by the holotype of $C$. atrox. Because it is the only pterosaur known from the Santana Formation that is likely to have had cervicals similar to those of UMGI M4895, and is also represented by an individual of corresponding size, these cervicals are tentatively assigned to Cearadactylus. Only more complete specimens will enable this problem to be resolved further.

\section{Cearadactylus and the evolutionary history of ctenochasmatid pterosaurs}

An outline of the temporal history and palaeobiogeography of the Ctenochasmatidae (Fig. 6) was reconstructed by combining data on the stratigraphic and geographic distribution of ctenochasmatid pterosaurs (Wellnhofer 1991a, Unwin et al. 2000) with the phylogenies presented in Fig. 4. To set this history within a general context, the temporal ranges of the other main clades of pterodactyloid pterosaurs, based on a detailed analysis of pterosaur phylogeny (Unwin in press) are also shown.

It seems likely that the Ctenochasmatidae originated before the Tithonian, since representatives of both main clades, the Ctenochasmatinae and the Gnathosaurinae are known from the Solnhofen Limestone of Bavaria (Wellnhofer 1970). Both clades persisted throughout the Lower Cretaceous, but neither is known from the Upper Cretaceous (Fig. 6A). Pterodaustro, the last record for the Ctenochasmatinae, is Albian, as is Cearadactylus, the last record for the Gnathosaurinae. So far, Jurassic ctenochasmatids have only been reported from Europe (Fig. 6B), but in the Cretaceous this group achieved a near global distribution (Fig. 6C), and both main subclades were also widely distributed. The proximity of all the major land masses in the Late Jurassic (Smith et al. 1994) doubtless aided dispersal, although these flying animals probably had little difficulty crossing the usual barriers to distribution such as seaways, or mountains.

The most recent common ancestor of the Ctenochasmatinae and the Gnathosaurinae was probably a small to medium-sized pterosaur, and rather similar in morphology to Pterodactylus, although with a larger tooth count. Subsequent evolution within the two subclades appears to have proceeded in different directions. In the Ctenochasmatinae, the jaws became even more elongate and acquired a distinctive curvature, while the teeth became finer, more numerous and shifted to a vertical orientation within the jaw. Unlike many other clades of pterodactyloids, ctenochasmatines appear to have remained of a relatively modest size throughout their history: Pterodaustro and the similarly sized Eosipterus are only slightly larger than Ctenochasma.

In the Gnathosaurinae, by contrast, the tooth count was reduced, Huanhepterus an early Lower Cretaceous form (Dong 1984) has only 25 pairs compared to $30-32$ pairs in the Late Jurassic forms Gnathosaurus (Wellnhofer 1970) and Plataleorhynchus (Howse \& Milner 1995), while Cearadactylus has, at most, 15 pairs in the rostrum. In addition, the teeth were relatively larger than those of basal gnathosaurines, more widely spaced and, in Cearadactylus, variable in morphology. Moreover, in the Gnathosaurinae, later forms such as Huanhepterus are larger than the earliest known taxa and the stratigraphically youngest form, Cearadactylus, is even larger than Huanhepterus.

The trends noted above may reflect ecological changes related to diet. Ctenochasmatines appear to have become increasingly specialised for filter feeding (Wellnhofer 1978, 1991a), whereas in gnathosaurines, although basal forms seem to have been sieve feeders (Wellnhofer 1970, Howse \& Milner 1995) preying on invertebrates, there seems to have been a shift toward larger prey items leading ultimately, in the case of Cearadactylus, to a change to fish-catching (Leonardi \& Borgomanero 1985, Wellnhofer 1991a: 127). These changes in diet might also be related to the phyletic size increase evident in gnathosaurines.

Cearadactylus thus represents a striking example of morphological convergence, with many features related to fish-catching that also appear in ornithocheirids, but not in other ctenochasmatoids. Such features include tooth dimorphodonty, the remarkable similarity in the size, spacing and to some extent orientation of the teeth in both upper and lower jaws, and the strengthening of the skull (e.g. by deepening the mandibles and infilling the base of the orbit) to withstand relatively large loads rapidly applied to the anterior ends of the jaws. 


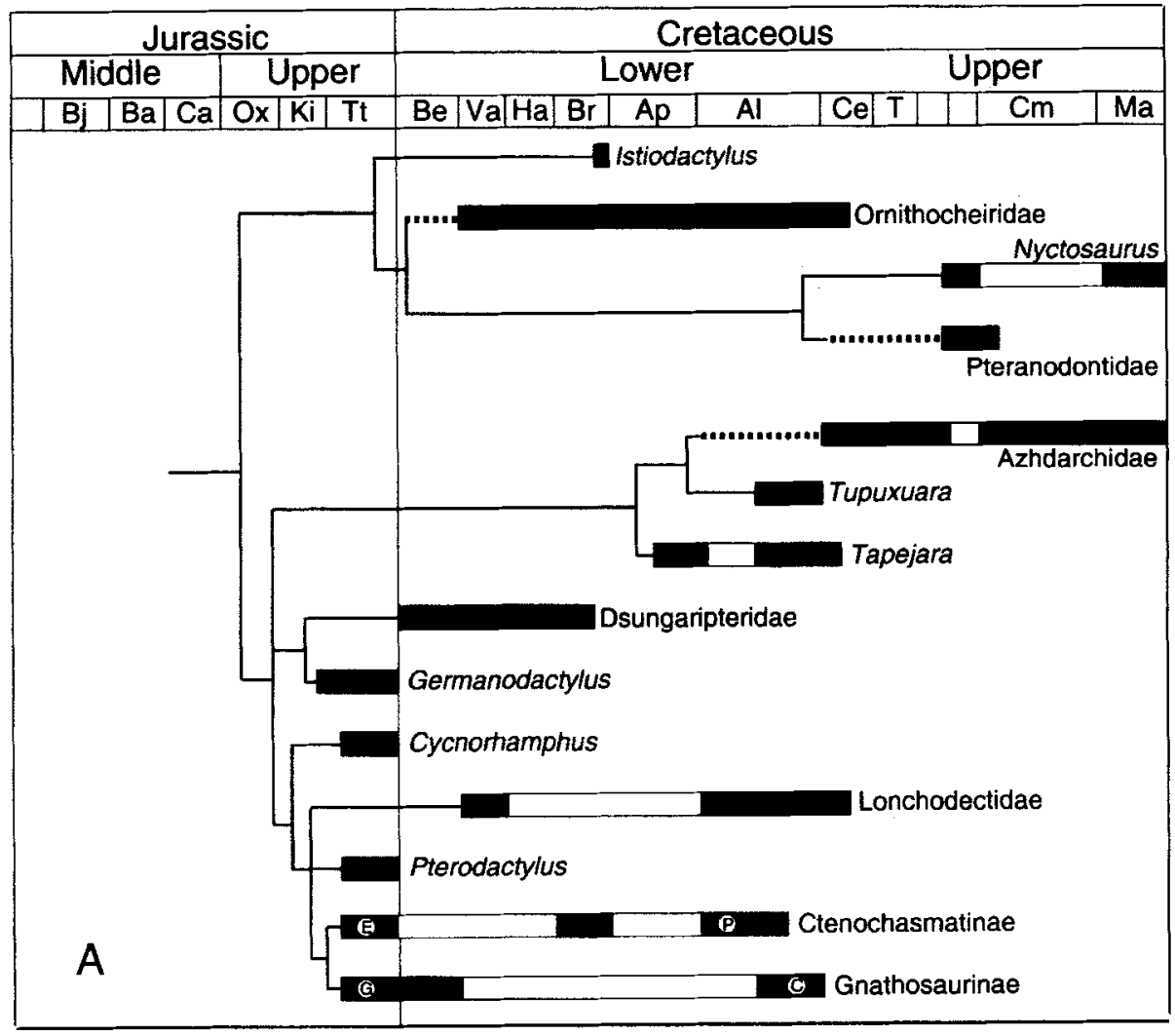

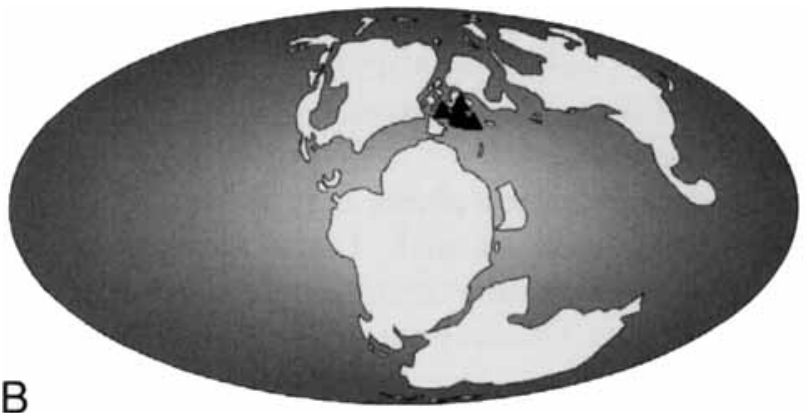

Upper Jurassic

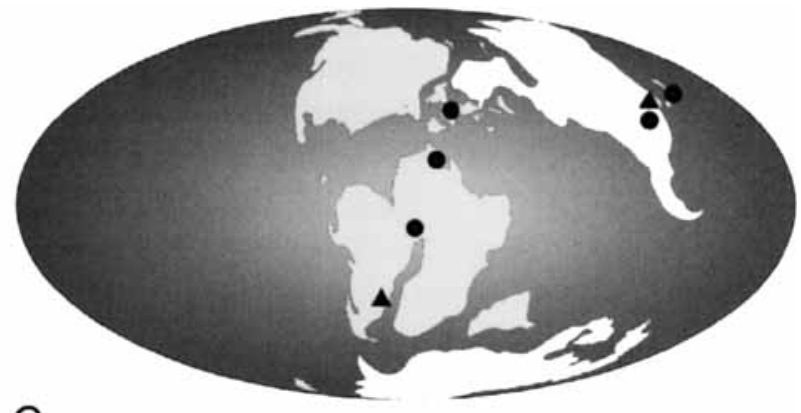

C

Lower Cretaceous

Fig. 6. Evolutionary history (A) of the Ctenochasmatidae and other pterodactyloid pterosaurs, reconstructed using the phylogenies shown in Fig. 4 and the known stratigraphic distribution of taxa representing the various clades (Wellnhofer 1991a, Unwin et al. 2000, Unwin 2001). Palaeogeographic distribution of the Ctenochasmatidae in (B) the Upper Jurassic and (C) the Lower Cretaceous showing fossil localities that have yielded gnathosaurines (circles) and ctenochasmatines (triangles). Maps based on Smith et al. (1994). Abbreviations: Al, Albian; Ap, Aptian; Ba, Bathonian; Be, Berriasian; Bj, Bajocian; Br, Barremian; C, Cearadactylus; Ca, Callovian; Ce, Cenomanian; Cm, Campanian; E, Ctenochasma; G, Gnathosaurus; Ha, Hauterivian; Ki, Kimmeridgian; Ma, Maastrichtian; Ox, Oxfordian; P, Pterodaustro; Tt, Tithonian; T, Turonian; Va, Valanginian.

\section{Acknowledgements}

I am very grateful to the following museums and institute staff for giving me access to their collections, loaning material and providing much useful information: A. Milner and S. Chapman, The Natural History Museum, London, England; C. Forbes, S. Etchells-Butler, D. Norman and the late D. Price, Sedgwick Museum, Cambridge, England; P. Wellnhofer, Bayerische Staatssammlung für Paläontologie und Geologie, Munich, Germany; G. Viohl, Jura Museum, Eichstätt, Germany; M. Manabe and Y. Tomida, National Science Museum, Tokyo, Japan; S. Nabana, Iwaki Museum of Coal and Fossils, Iwaki, Japan; and E. Frey, Staatssammlung für Naturkunde, Karlsruhe, Germany. G. Leonardi very kindly pro- vided illustrations and information on the holotype of Cearadactylus atrox. I thank N. Bakhurina, C. Bennett, M. Benton, M. Fastnacht, E. Frey, Junchang Lü, A. Kellner, D. Martill and P. Wellnhofer, for their helpful discussions of pterosaur systematics, the Department of Zoology, Reading University, Department of Earth Sciences, Bristol University and the Royal Society for funding aspects of this work and the staff of the Institut für Paläontologie, Museum für Naturkunde, Berlin for all their help and assistance. R. Soler-Gijon kindly translated various Portugese texts and I am especially grateful to M. Benton, J. Dunlop, C. Bennett, D. Martill and D. Naish for their comments on earlier versions of the text, R. Schoch for his translation of the abstract and Gloria Arratia for her editorial work on the MS. 


\section{References}

Bennett, S. C. 1989. A pteranodontid pterosaur from the Early Cretaceous of Peru, with comments on the relationships of Cretaceous pterosaurs. - Journal of Paleontology 63: 669-677.

- 1993. The ontogeny of Pteranodon and other pterosaurs. - Paleobiology 19: 92-106.

- 1994. Taxonomy and systematics of the Late Cretaceous pterosaur Pteranodon (Pterosauria, Pterodactyloidea). Occasional Papers of the Natural History Museum, The University of Kansas Lawrence, Kansas 169: 1-70.

- 1996. On the taxonomic status of Cycnorhamphus and Gallodactylus (Pterosauria: Pterodactyloidea). Journal of Paleontology 70: 335-338.

- 2001. The osteology and functional morphology of the Late Cretaceous pterosaur Pteranodon. - Palaeontographica Abteilung A 260: 1-153.

- 2002. Soft tissue preservation of the cranial crest of the pterosaur Germanodactylus from Solnhofen. - Journal of Vertebrate Paleontology 22: 43-48.

Berthou, P.-Y., Vianna, M. S. S. \& Campos, D. de A. 1990. Coupe de la Formation Santana dans le secteur de 'Pedra Branca' (Santana do Cariri) (Bassin d'Araripe, NE du Brésil): contribution à létude de la sedimentologie et des paléoenvironments. In Campos, D. de A., Vianna, M. S. S., Brito, P. M. \& Beurlen, G. (eds). Atas do I Simposio sobre a Bacia do Araripe e Bacias Interiores do Nordeste, Crato, 14-16 de Junho de 1990: 173-191.

Bonaparte, J. F. 1971. Descripción del cráneo y mandíbulas de Pterodaustro guinazui (Pterodactyloidea - Pterodaustriidae nov.) de la Formación Lagarcito, San Luis, Argentina. - Publicación del Museo Municipal de Ciencias Naturales Mar del Plata 1: 263-272.

Broili, F. 1924. Ctenochasma ist ein Flugsaurier. - Sitzungsberichte der Bayerischen Akademie der Wissenschaften, mathematisch naturwissentschaftliche Abteilung: 13-30.

- 1936. Weitere Beobachtungen an Ctenochasma. - Sitzungsberichte der Bayerischen Akademie der Wissenschaften, mathematisch naturwissentschaftliche Abteilung: 137-156.

Buisonjé, P. H. de 1980. Santandactylus brasilensis nov. gen. nov. sp., a long necked, large pterosaurier from the Aptian of Brasil. II. - Proceedings of the Koninklijke Nederlandse Akademie van Wetenschappen, Series B 83 (2): 158-172.

- 1981. Ctenochasma porocristata nov. sp. from the Solnhofen Limestone, with some remarks on other Ctenochasmatidae. - Proceedings of the Koninklijke Nederlandse Akademie van Wetenschappen, Series B 84: 411-436.

Campos, D. de A., Ligabue, G. \& Taquet, P. 1984. Wing membrane and wing supporting fibers in a flying reptile from the Lower Cretaceous of the Chapada de Araripe (Aptian, Ceará State, Brazil). In Reif, W. E. \& Westphal, F. (eds). Proceedings of the Third Symposium on Mesozoic Terrestrial Ecosystems, Short Papers: 37-39, Attempto Verlag, Tübingen.

Campos, D. de A. \& Kellner, A. W. A. 1985. Panorama of the flying reptiles study in Brazil and South America. Anais da Academia Brasileira de Ciências 57: 453-466.

- 1997. Short note on the first occurrence of Tapejaridae in the Crato Member (Aptian), Santana Formation, Araripe Basin, Northeast Brazil. - Anais da Academia Brasileira de Ciências 69: 83-87.

Chiappe, L. M., Kellner, A. W. A., Rivarola, D., Davila, S. \& Fox, M. 2000. Cranial morphology of Pterodaustro guinazui (Pterosauria: Pterodactyloidea) from the Lower Cretaceous of Argentina. - Contributions in Science, Natural History Museum of Los Angeles County 483: 1-19.

Dalla Vecchia, F. M. 1993. Cearadactylus? ligabuei nov. sp., a new early Cretaceous (Aptian) pterosaur from Chapada do Araripe (Northeastern Brazil). - Bollettino della Società Paleontologica Italiana 32: 401-409.
Dalla Vecchia, F. M. \& Ligabue, G. 1993. On the presence of a giant pterosaur in the Lower Cretaceous (Aptian) of Chapada do Araripe (northeastern Brazil). - Bollettino della Società Paleontologica Italiana 32: 131-136.

Dong Zhiming 1982. On a new pterosaur (Huanhepterus quingyanensis, gen. et sp. nov.) from Ordos, China. Vertebrata Palasiatica 20: $115-121$.

Fastnacht, M. 2001. First record of Coloborhynchus (Pterosauria) from the Santana Formation (Lower Cretaceous) of the Chapada do Araripe, Brazil. - Paläontologische Zeitschrift 75 (1): 23-36.

Frey, E. \& Martill, D. M. 1994. A new pterosaur from the Crato Formation (Lower Cretaceous, Aptian) of Brazil. Neues Jahrbuch für Geologie und Paläontologie, Abhandlungen 194: $379-412$.

- in press. A new crested ornithocheirid from the Lower Cretaceous of NE Brazil and the unusual death of an unusual pterosaur. In Buffetaut, E. (ed.). Two Hundred Years of Pterosaurs; Geological Society, London.

Howse, S. C. B. 1986. On the cervical vertebrae of the Pterodactyloidea (Reptilia: Archosauria). - Zoological Journal of the Linnean Society 88: $307-328$.

Howse, S. C. B. \& Milner, A. R. 1995. The pterodactyloids from the Purbeck Limestone Formation of Dorset. - Bulletin of the Natural History Museum, London (Geology) 51: 73-88.

Ji Shuan \& Ji Qiang 1997. Discovery of a new pterosaur in western Liaoning, China. - Acta Geologica Sinicia 71 (1): 1-6. [In Chinese].

Kaup, J. J. 1834. Versuch einer Eintheilung der Saugethiere in 6 Stämme und der Amphibien in 6 Ordnungen. - Isis 3: $311-315$.

Kellner, A. W. A. 1984. Ocorrência de uma mandíbula de pterosauria (Brasileodactylus araripensis, nov. gen.; nov. sp.) na formação Santana, Cretáceo da Chapada do Araripe, Ceará, Brasil. - 33 Congresso Brasileiro de Geologia, Anais 2: 578-590.

- 1989. A new edentate pterosaur of the Lower Cretaceous from the Araripe Basin, Northeast Brazil. - Anais da Academia Brasileira de Ciências 61(4): 439-446.

- 1990. Os répteis voadores do Crétaceo Brasileiro. - Anuário do Instituto de Geociências, CCMN, UFRJ, ano 1989: 86-106.

- 1995a. Description of a juvenile specimen of Tapejara (Pterodactyloidea, Tapejaridae) from Brazil. - Journal of Vertebrate Paleontology 15 (supp. to nr. 3): 38A-39A.

- 1995b. The relationships of the Tapejaridae (Pterodactyloidea) with comments on pterosaur phylogeny. In Sun Ailing \& Wang Yuanqing (eds). Sixth Symposium on Mesozoic Terrestrial Ecosystems and Biota. Short Papers: 79-82, China Ocean Press, Beijing.

- 1996. Pterosaur phylogeny. - Journal of Vertebrate Paleontology 16 (supp. to nr. 3): 45A.

- 1997. Reinterpretation of a remarkably well preserved pterosaur soft tissue from the Early Cretaceous of Brazil. - Journal of Vertebrate Paleontology 16: 718-722.

Kellner, A. W. A. \& Campos, D. de A. 1988. Sobre un novo pterosauro com crista sagital da Bacia do Araripe, Cretáceo Inferior do Nordeste do Brasil. (Pterosauria, Tupuxuara, Cretaceo, Brasil). - Anais da Academia Brasileira de Ciências 60 (4): 459-469.

- 1994. A new species of Tupuxuara (Pterosauria, Tapejaridae) from the Early Cretaceous of Brazil. - Anais da Academia Brasileira de Ciências 66 (4): 467--473.

Kellner, A. W. A. \& Tomida, Y. 2000. Description of a new species of Anhangueridae (Pterodactyloidea) with comments on the pterosaur fauna from the Santana Formation (Aptian-Albian), northeastern Brazil. - National Science Museum Monographs, Tokyo 17: 1-135.

Knoll, F. 2000. Pterosaurs from the Lower Cretaceous (?Berriasian) of Anoual, Morocco. - Annales de Paléontologie 86: 157-164. 
Kuhn, O. 1967. Die fossile Wirbeltierklasse Pterosauria. 52 pp., Oeben, Krailing bei München.

Leonardi, G. \& Borgomanero, G. 1983. Cearadactylus atrox nov. gen., nov. sp.: novo Pterosauria (Pterodactyloidea) da Chapada do Araripe, Ceará, Brasil. - 7 Congresso Brasileiro de Paleontologia, Resumos: 17.

- 1985. Cearadactylus atrox nov. gen., nov. sp.: novo Pterosauria (Pterodactyloidea) da Chapada do Araripe, Ceará, Brasil. - Coletânea de Trabalhos Paleontológicos, Série Geologia, Brasilia: 75-80.

- 1987. The skeleton of a pair of wings of a pterosaur (Pterodactyloidea ? Ornithocheridae, cf. Santanadactylus) from the Santana formation of the Araripe Plateau, Ceará, Brazil. - 10 Congresso Brasileiro de Paleontologia, Anais, Rio de Janeiro 1: 123-129.

Maisey, J. G. 1991. (ed.). Santana fossils: an illustrated atlas. 459 pp., T.F.H., Neptune City, New Jersey.

Martill, D. M. 1993. Fossils of the Santana and Crato Formations, Brazil. - The Palaeontological Association Field Guides to Fossils 5: 1-159.

Martill, D. M. \& Frey, E. 1998. A new pterosaur lagerstätte in N.E. Brazil (Crato Formation; Aptian, Lower Cretaceous): preliminary observations. - Oryctos 1: 79-85.

- 1999. A possible azhdarchid pterosaur from the Crato Formation (Early Cretaceous, Aptian) of northeast Brazil. - Geologie en Mijnbouw 78: 315-318.

Martill, D. M. \& Unwin, D. M. 1989. Exceptionally well preserved pterosaur wing membrane from the Cretaceous of Brazil. - Nature 340: 138-139.

Martill, D. M. \& Wilby, P. 1993. In Martill, D. M. (ed.). Fossils of the Santana and Crato Formations, Brazil: 20-50, The Palaeontological Association Field Guides to Fossils 5: $1-159$.

Martill, D. M., Wilby, P. \& Unwin, D. M. 1990. Stripes on a pterosaur wing. - Nature 346: 116.

Meyer, H. von 1834. Gnathosaurus subulatus, ein Saurus aus dem lithographischen Schiefer von Solnhofen. - Museum Senckenbergianum 1 (3): 1-26.

Miller, H. W. 1972. The taxonomy of the Pteranodon species from Kansas. - Transactions of the Kansas Academy of Sciences 74: 1-19.

Nesov, L. A. 1984. [Upper Cretaceous pterosaurs and birds from Central Asia]. - Paleontologicheskii Zhurnal 1984 (1): $47-57$ [In Russian].

Nopcsa, F. 1928. The genera of reptiles. - Palaeobiologica 1: $163-188$

Owen, R. 1870. Monograph of the fossil Reptilia of the Liassic Formations. - Monographs of the Palaeontographical Society 27: $41-81$.

Owen, R. 1874. Monograph on the fossil Reptilia of the Mesozoic formations. - Monographs of the Palaeontographical Society: $1-14$.

Padian, K. 1984. A large pterodactyloid pterosaur from the Two Medicine Formation (Campanian) of Montana. Journal of Vertebrate Palacontology 4: 516-524.

- 1986. A taxonomic note on two pterodactyloid families. Journal of Vertebrate Paleontology 6: 289.

Peters, D. 1997. A new phylogeny for the Pterosauria. - Journal of Vertebrate Paleontology 17 (supp. to nr. 3): 69A.

Plieninger, F. 1901. Beiträge zur Kenntnis der Flugsaurier. Palaeontographica 48: $65-90$.

- 1907. Die Pterosaurier der Juraformation Schwabens. Paläontographica 53: 209-313.

Pons, D., Berthou, P.-Y. \& Campos D. de A. 1990. Quelques observations sur la palynologie de l'Aptien Supérieur et de l'Albien du Bassin d'Araripe (N.E. du Brésil). In Campos, D. de A., Vianna, M. S. S., Brito, P. M. \& Beurlen, G. (eds.). Atas do I Simposio sobre a Bacia do Araripe e Bacias Interiores do Nordeste, Crato, 14-16 de Junho de 1990: 241-252.

Price, L. I. 1971. A presenca de Pterosauria no Cretaceo Inferior da Chapada do Araripe, Brasil. - Anais da Academia Brasileira de Ciências 43 (suppl.): 452-461.
Quenstedt, F. A. 1855. Über Pterodactylus suevicus im lithographischen Schiefer Württembergs. Doctoral thesis, Universität Tübingen.

Sanchez, T. M. 1973. Redescripción del cráneo y mandíbulas de Pterodaustro guinazui Bonaparte (Pterodactyloidea, Pterodaustriidae). - Ameghiniana 10: 313-325.

Sayão, J. M. \& Kellner, A. W. A. 2000. Description of a pterosaur rostrum from the Crato Member, Santana Formation (Aptian-Albian) northeastern Brazil. - Boletim do Museu Nacional Nova Serie Rio de Janeiro - Brasil, Geologia 54: 1-8.

Seeley, H. G. 1869. Index to the Fossil Remains of Aves, Ornithosauria and Reptilia. 143 pp., Deighton, Bell \& Co., Cambridge.

- 1870. The Ornithosauria: an elementary study of the bones of pterodactyles, made from fossil remains found in the Cambridge Greensand, and arranged in the Woodwardian Museum of the University of Cambridge. 135 pp., Deighton, Bell \& Co., Cambridge.

Smith, A. G., Smith, D. G. \& Funnell, B. M. 1994. Atlas of Mesozoic and Cenozoic Coastlines. ix + 99 pp., Cambridge University Press, Cambridge.

Swofford, D. L. 1993. PAUP: Phylogenetic Analysis Using Parsimony, Version 3. 1. 1. Illinois Natural History Survey, Champagne.

Unwin, D. M. 1988. New pterosaurs from Brazil. - Nature 332: $398-399$.

- 1992a. The phylogeny of the Pterosauria. - Journal of Vertebrate Paleontology 12 (suppl. to nr. 3): 57A.

- 1992b. Pterosaurs from the Purbeck (Cretaceous: Berriasian) of England, with comments on the systematics and evolutionary history of the Ctenochasmatidae. Abstracts of the Second Georges Cuvier meeting, Montbeliard, France.

- 1995. Preliminary results of a phylogenetic analysis of the Pterosauria (Diapsida: Archosauria). In Sun Ailing \& Wang Yuanqing (eds). Sixth Symposium on Mesozoic Terrestrial Ecosystems and Biota. Short Papers: 69-72, China Ocean Press, Beijing.

- 2001. An overview of the pterosaur assemblage from the Cambridge Greensand (Cretaceous) of Eastern England. - Mitteilungen Museum für Naturkunde Berlin, Geowissenschaftlichen Reihe 4: 189-222.

- in press. On the phylogeny and evolutionary history of pterosaurs. In Buffetaut, E. (ed.). Two Hundred Years of Pterosaurs; Geological Society, London.

Unwin, D. M. \& Bakhurina, N. N. 2000. Pterosaurs from Russia, Middle Asia and Mongolia. In Benton, M. J., Shiskin, M., Unwin, D. M. \& Kurochkin, E., (eds). The Age of Dinosaurs in Russia and Mongolia: 420-433, Cambridge University Press, Cambridge.

Unwin, D. M. \& Heinrich, W.-D. 1999. On a pterosaur jaw from the Upper Jurassic of Tendaguru (Tanzania). - Mitteilungen aus dem Museum für Naturkunde in Berlin, Geowissenschaftlichen Reihe 2: 121-134.

Unwin, D. M. \& Lü Junchang. 1997. On Zhejiangopterus and the relationships of pterodactyloid pterosaurs. - Historical Biology 12: 199-210.

Unwin, D. M., Lü Junchang \& Bakhurina, N. N. 2000. On the systematic and stratigraphic significance of pterosaurs from the Lower Cretaceous Yixian Formation (Jehol Group) of Liaoning, China. - Mitteilungen aus dem Museum für Naturkunde in Berlin, Geowissenschaftlichen Reihe 3: 181-206.

Viscardi, P., Dyke, G. J., Wilkinson, M. \& Rayner, J. M. V. 1999. Missing data and the phylogeny of the Pterosauria. - Journal of Vertebrate Paleontology 19 (suppl. to nr. 3): $83 \mathrm{~A}$.

Wellnhofer, P. 1970. Die Pterodactyloidea (Pterosauria) der Oberjura Plattenkalke Süddeutschlands. - Abhandlungen der Bayerischen Akademie der Wissenschaften zu München, Mathematisch-Naturwisenschaftlichen Klasse 141: $1-133$. 
- 1975a. Die Rhamphorhynchoidea (Pterosauria) der Oberjura-Plattenkalke Süddeutschlands. II. Systematische Beschreibung. - Palaeontographica Abteilung A 148: 132-186.

- 1975b. Die Rhamphorhynchoidea (Pterosauria) der Oberjura-Plattenkalke Süddeutschlands. I. Allgemeine Skelettmorphologie. - Palaeontographica Abteilung A 148: $1-33$.

- 1977. Araripedactylus dehmi nov. gen., nov. sp., ein neuer Flugsaurier aus der Unterkreide von Brasilien. - Mitteilungen der Bayerischen Staatssammlung für Paläontologie und historische Geologie 17: 157-167.

- 1978. Handbuch der Paläoherpetologie. Teil 19, Pterosauria: 82 pp., Gustav Fischer Verlag, Stuttgart.

- 1985. Neue Pterosaurier aus der Santana Formation (Apt.) der Chapada do Araripe, Brasilien. - Palaeontographica Abteilung A 187: 105-182.

- 1987. New crested pterosaurs from the Lower Cretaceous of Brazil. - Mitteilungen der Bayerischen Staatssammlung für Paläontologie und historische Geologie 27: $175-186$.

- 1988. Terrestrial locomotion in pterosaurs. - Historical Biology 1: 3-16.

- 1991a. The Illustrated Encyclopedia of Pterosaurs. 192 pp., Salamander Books, London.
- 1991b. Santana Formation pterosaurs. In Maisey, J. G. (ed.). Santana Fossils: an Illustrated Atlas: 351-370, T.F.H., Neptune City, New Jersey.

- 1991c. Weitere Pterosaurierfunde aus der Santana-Formation (Apt) der Chapada do Araripe, Brasilien. - Palaeontographica Abteilung A 215: 43-101.

Wellnhofer, P. \& Kellner, A. W. A. 1991. The skull of Tapejara wellnhoferi Kellner (Reptilia: Pterosauria) from the Lower Cretaceous Santana Formation of the Araripe Basin, Northeastern Brazil. - Mitteilungen der Bayerischen Staatssammlung für Paläontologie und historische Geologie 31: 89-106.

Wellnhofer, P., Buffetaut, E. \& Gigase, P. 1983. A pterosaurian notarium from the Lower Cretaceous of Brazil. Paläontologische Zeitschrift 57: 147-157.

Wild, R. 1978. Die Flugsaurier (Reptilia, Pterosauria) aus der Oberen Trias von Cene bei Bergamo. - Bollettino della Società Paleontologica Italiana 17: 176-256.

Young, C. C. 1964. On a new pterosaurian from Sinkiang, China. - Vertebrata PalAsiatica 8: 221-255.

- 1973. [Wuerho pterosaurs]. - Special Publication of the Institute of Vertebrate Palaeontology and Palaeoanthropology, Academia Sinica 11: 18-34 [In Chinese]. 